\title{
Observaciones al Proyecto de Ley de Jurisdicción Voluntaria en España, de Octubre de 2006
}

ANTONIO FERNÁNDEZ DE BUJÁN

Catedrático de la Universidad Autónoma de Madrid. Vocal de la Ponencia del Anteproyecto de Ley de Jurisdicción Voluntaria. antonio.bujan@uam.es

Sumário: 1) Introducción. El iter prelegislativo de la jurisdicción voluntaria. 2) Novedades del Proyecto de Ley respecto del Anteproyecto de junio de 2006. 3) Elementos constitutivos del núcleo esencial de la reforma legal. 4) Propuestas de mejora del texto normativo. Especial mención a la ausencia de reserva jurisdiccional y al menoscabo de garantías en el procedimiento judicial. 5) Reflexiones críticas sobre cuestiones varias. 6) Procedimiento común a Jueces y Secretarios Judiciales. 7) Sustancial modificación del marco competencial. 8) De los Procedimientos Especiales. 9) De las Disposiciones Complementarias. 10) Valoración global final del nuevo marco normativo de la Jurisdicción Voluntaria.

Síntesis: La sustancial modificación del marco competencial se configura como la más relevante novedad de la reforma: se deslinda entre las competencias que continúan atribuidas a los Jueces y aquellas otras que, en el ámbito de la propia JV, se atribuyen a Notarios y Registradores de la Propiedad y Mercantiles, y se procede a la redistribución de competencias entre Jueces y Secretarios Judiciales, en el seno del órgano jurisdiccional. La configuración institucional de Notarios y Registradores como agentes de la JV, la posibilidad de acudir de forma opcional a uno u otro operador jurídico en determinadas materias, la ausencia de reserva jurisdiccional, la administrativación de la institución, y el mantenimiento de la JV en el marco del ejercicio pacífico de los derechos, podrían ser asimismo considerados los núcleos esenciales del texto prelegislativo. 
El pasado veinte de octubre, el Consejo de Ministros aprobó la remisión a las Cortes Generales del Proyecto de Ley de Jurisdicción Voluntaria, JV, para facilitar y agilizar la tutela y garantía de los derechos de la persona, en materia civil y mercantil. En el marco del Estado constitucional de Derecho, la reforma de la JV era una de las piezas que quedaba todavía por encajar en el organigrama de la Administración de Justicia, dado que el legislador de la Ley Procesal Civil del año 2000, había optado, en lo que constituye la primera novedad respecto de las leyes procesales anteriores, por regular la JV en una Ley específica, siguiendo también en este punto el modelo constitucional alemán

La ley de Enjuiciamiento Civil, LEC, por la que se rige la jurisdicción contenciosa, establece en su Disposición Final 18 a que: < En el plazo de un año, a contar de la fecha de entrada en vigor de esta Ley, el Gobierno remitirá a las Cortes Generales un proyecto de Ley sobre jurisdicción voluntaria>. El cumplimiento del mandato del legislador, impregnado de voluntarismo político, en lo atinente al breve plazo previsto, ante la magnitud y complejidad de la tarea, se inicia, en el año 2002, con la constitución, en el seno de la Sección Segunda de la Comisión General de Codificación, máximo órgano asesor del Ministerio de Justicia en las tareas prelegislativas, de una Ponencia, compuesta de siete miembros, a la que se encarga la elaboración de un texto preparatorio de Anteproyecto de Ley de Jurisdicción Voluntaria ${ }^{25}$

En junio de 2005, la Ponencia concluye su Propuesta de Anteproyecto, con un contenido de 308 artículos y Diez Disposiciones Complementarias, < valoradas y tenidas muy en cuenta- conforme se afirma en su Exposición de Motivos-las observaciones que a su articulado le fueron formuladas por las Secciones de Derecho Mercantil y de Derecho Civil de la Comisión General de Codificación>.

El texto normativo elaborado por la Ponencia, es publicado en el Boletín Informativo del Ministerio de Justicia en octubre del año 2005 como Anteproyecto

\footnotetext{
${ }^{25}$ El presente estudio se realiza en el marco del Proyecto de Investigación ,del que el autor es el Investigador Principal, SEJ 2005-08535. La reforma en curso de la jurisdicción voluntaria: perspectiva histórica,regulación vigente, propuestas de futuro y Derecho Comparado.
}

Vid, entre otros autores, en relación con las más recientes aportaciones en la materia : Fernández de Buján, La Jurisdicción Voluntaria. Madrid 2001; Id.La reforma de la Jurisdicción Voluntaria :problemas, interrogantes, soluciones, La Ley,23-3-2005; Id. El nuevo perfil de la Jurisdicción Voluntaria en el Anteproyecto de Ley de octubre de 2005.De la tutela de relaciones jurídico privadas a la protección de intereses generales, públicos o sociales. La Ley, 8-6-2006 Id.La Jurisdicción Voluntaria.El Anteproyecto de junio de 2006,en El Notario del siglo XXI, agosto de 2006; De Prada González, En torno a la futura ley de jurisdicción voluntaria,en El Notario del siglo XXI,diciembre 2005; Seoane Cacharrón, Breve examen crítico del Anteproyecto de Ley de Jurisdicción Voluntaria del Ministerio de Justicia de 1 de junio de 2006, La Ley, 28-9-2006 , y la bibliografía citada .en estos estudios 
de Jurisdicción Voluntaria: <como texto preliminar de una nueva regulación de la jurisdicción voluntaria, sin duda necesaria, por lo que se hace pública por su evidente interés para la comunidad jurídica, al objeto de propiciar su conocimiento y libre discusión>, según se afirma en la Nota Editorial , que antecede a la Memoria Explicativa que acompaña al texto normativo, integrado por una Exposición de Motivos, 306 artículos y 10 Disposiciones Complementarias.

La puesta en marcha de la maquinaria legislativa, a partir de este primer paso relevante del prelegislador, continua con la revisión interna en el Ministerio de Justicia de la Propuesta de la Ponencia y su materialización en el Anteproyecto de Ley de Jurisdicción Voluntaria, aprobado en Consejo de Ministros de 2 de junio de 2006, e integrado por una Exposición de Motivos, ciento ochenta y cuatro artículos, repartidos en nueve Títulos, y dieciocho Disposiciones Complementarias, de las cuales ocho son adicionales, una transitoria, una derogatoria y ocho finales.

El Proyecto de Ley de Jurisdicción Voluntaria, para facilitar y agilizar la tutela y garantía de los derechos de la persona en materia civil y mercantil, consta de una Exposición de Motivos, 202 artículos, distribuidos en X Títulos y 17 Disposiciones Complementarias y reproduce, con escasas modificaciones, a las que me refiero en el apartado siguiente, el texto del Anteproyecto de Ley de junio de 2006.

La vigente regulación de la JV, se contiene, en la mayoría de sus manifestaciones, en el Libro III de la Ley de Enjuiciamiento Civil de 1881. La previsión en el Proyecto de un procedimiento global y unitario, que sustituirá al conjunto de disposiciones parciales contenidas en la primera y segunda parte del Libro III de la Ley de 1881, por el que se regirán los expedientes sustanciados ante Jueces y Secretarios Judiciales, debería suponer la inclusión en la nueva Ley de los procedimientos que se creen en el futuro, por razones de coherencia formal, sistemática e incluso educativa de la propia legislación. Parece percibirse, en este sentido, en el espíritu del prelegislador, una clara voluntad codificadora de la materia - con excepciones opinables, en atención a su clara naturaleza voluntaria, que cabría tan sólo justificar por respeto a la sistemática vigente, derivada de su inclusión en la LEC, como pueden ser, las diligencias preliminares, la separación y divorcio por mutuo consenso, el reconocimiento de eficacia civil a las resoluciones de tribunales eclesiásticos sobre nulidad de matrimonio canónico y a las resoluciones pontificias sobre matrimonio rato y no consumado, o la puesta en posesión de bienes a quien los hubiere obtenido por herencia, si no estuvieren poseídos por nadie a título de dueño o usufructuario - que se ha materializado en el traslado de otros cuerpos legales, como el Código Civil, el Código de Comercio o la Ley Hipotecaria, de procedimientos singulares al texto normativo del Proyecto..

Desde que, por primera vez, se procedió a contraponer la jurisdicción contenciosa de la jurisdicción voluntaria en un texto del Digesto de Justiniano, correspondiente a un jurista clásico romano, del siglo III de nuestra era, se entiende, hasta el momento presente, por actuaciones de JV., en sentido estricto, aquellos 
supuestos en los que se prevé en una norma jurídica de derecho material, la intervención de la autoridad judicial, a solicitud de uno o varios promoventes, o bien de oficio, o a instancia del Ministerio Público, sin que exista proceso, es decir, contienda por lesión de derecho subjetivo o interés legítimo, o conflicto de intereses relevante inter partes.

Es la JV, por otra parte, una institución caracterizada por la estrecha conexión con la vida diaria de los ciudadanos, por la interrelación entre la norma procedimental y la base de derecho material sobre la que se sustenta, así como por la relevante trascendencia práctica de muchos de sus procedimientos, como por ejemplo los atinentes a: conciliación, reconocimiento de la filiación no matrimonial, tutela, curatela, guarda de hecho, acogimiento familiar, adopción, declaración de ausencia y fallecimiento, protección de personas con discapacidad, aceptación de una herencia, intromisiones en el honor, intimidad o propia imagen del menor o incapacitado, extracción de órganos de donantes vivos, autorización judicial de los tratamientos no voluntarios de las personas con trastornos psíquicos, discordancias en el ejercicio de la patria potestad atinentes a la custodia o a las relaciones del menor con sus parientes y allegados, discordancias en el seno de la relación conyugal , expedientes de dominio, fijación del plazo para el cumplimiento de una obligación, declaración de herederos cuando no existe o no es válido el testamento o en materia de derecho mercantil, la convocatoria de una Junta General a instancia de una minoría de socios o el nombramiento de un tercer perito en un contrato de seguro, cuando los peritos nombrados por el asegurador y el asegurado, no se ponen de acuerdo en la determinación del daño producido.

Se trata de supuestos en los que el justiciable debe percibir de manera directa que se hace efectivamente justicia, en atención a la brevedad, simplificación, concentración e inmediatez en la tramitación del expediente .

\section{c Novedades del Proyecto de Ley Respecto DEL ANTEPRoYecto DE JUNIO de 2006}

Las principales novedades que, de forma acertada, a mi juicio, aporta el Proyecto, en relación con el texto del Anteproyecto son:

a) La regulación del procedimiento de autorización judicial de los tratamientos no voluntarios de las personas con trastornos psíquicos, contenida en el capítulo IX, arts 84 a 87, del título IV, correspondiente a la JV en materia de personas.

b) La regulación los procedimientos de derecho marítimo, en el título X, que han quedado reducidos a tres supuestos: la protesta de mar e incidencias del viaje, la liquidación de avería gruesa y el depósito y venta de mercancías y equipajes en el transporte marítimo. De forma singular se mantiene al respecto la habilidad de todos los días y horas sin excepción, en la sustanciación de los expedientes en 
la materia, art. 189, lo que constituye el régimen general en JV, conforme al todavía vigente art. 1812 de la LEC de 1881. La regulación establecida exigirá un estudio detenido en el futuro en orden a la justificación de los procedimientos suprimidos respecto a la previsión del Anteproyecto de octubre de 2005, en relación con alguno de los cuales, como la venta del buque, o el extravío, sustracción o destrucción del conocimiento de embarque, se había previsto, sin embargo, la competencia, en el Anteproyecto de octubre de junio de 2006. Los varios cambios de criterio parece que ponen de manifiesto que no se encuentran suficientemente asentados los principios informadores en esta materia, que se encuentra en pleno proceso de reforma..

c) La armonización de la entrada en vigor de los procedimientos atribuidos a los distintos operadores jurídicos, en atención a que una interpretación literal de las disposiciones contenidas en el Anteproyecto de junio, podía dar lugar a una entrada en vigor en fechas diferentes de la normativa atinente a los distintos titulares de competencias en JV.

d) La atribución de competencia al Secretario Judicial y al Registrador mercantil, para proceder a la designación de un experto independiente que fije la cuantía de la indemnización compensatoria, a solicitud del socio que se considere perjudicado por la relación de canje establecida, conforme a la Disposición Adicional cuarta, apartado e,

e) La previsión señalada en la Memoria Justificativa que, sin embargo, no se ha llevado al texto legislativo, parece que por olvido, conforme a la cual $<$ la disposición final séptima recoge el título competencial a favor del Estado "sin perjuicio de las necesarias especialidades que en este orden se deriven de las particularidades del derecho sustantivo de las Comunidades Autónomas”>

f) La necesidad de que el desarrollo de la comparecencia se registre en soporte apto para la grabación y reproducción del sonido y de la imagen, de conformidad con lo dispuesto en la Ley de Enjuiciamiento Civil (art. 22.5).

g) La introducción de un trámite de conclusiones (art. 22.6), en el procedimiento judicial, conforme al cual se establece que, una vez practicadas las pruebas, el Juez o Secretario Judicial, titulares del procedimiento, permitirá a los interesados formular oralmente sus conclusiones.

En el periodo de tiempo que abarque la tramitación del Proyecto de Ley en sede parlamentaria, corresponde a los protagonistas de la Justicia, interesados y afectados por la reforma en ciernes, doctrina científica y jurisprudencial, profesionales del derecho y de la economía de la empresa y expertos en cualquiera de las materias reguladas, la labor de enunciar problemas, suscitar dudas y proponer soluciones, en aras de coadyuvar a la mejora técnica del texto propuesto y de hacerlo en conexión con la realidad social, al propio tiempo que con vocación de permanencia, en la estela de la deseable seguridad jurídica que debe procurar toda reforma legislativa, lo que redundará, en definitiva, a contribuir a dar respuesta, también en esta parcela del Ordenamiento al desafio de una Justicia más moderna y eficaz. 


\section{$\checkmark$ Elementos Constitutivos del Núcleo ESENCIAL DE LA REFORMA}

Procederé de forma previa a hacer explícita mi valoración positiva del propio hecho de que la reforma se haya puesto en marcha y que los autores haya comenzado a ocuparse de su estudio. Se ha procedido a una profunda y necesaria revisión - un cambio legislativo de gran calado, en expresión contenida en el apartado cuarto de la Memoria - de una institución, como es la JV, que había suscitado hasta el momento presente un escaso interés en la doctrina - a salvo de las valiosas aportaciones de González Poveda, Ramos Méndez y Almagro - y en el desarrollo argumentativo de la Jurisprudencia.

Acierta, a mi juicio, el Proyecto, en la conformación de los ejes que se configuran como el núcleo esencial del futuro texto legal:

a) La desjudicialización de procedimientos, en materia de derechos reales, obligaciones, sucesiones, derecho mercantil y derecho marítimo, que atribuidos ,en su momento, a los jueces en atención a explicables decisiones de oportunidad, tradición histórica, orden público u ordenación del sistema, no continúan vigentes en el momento actual, y su atribución a Notarios y a Registradores de la Propiedad y Mercantiles, en atención a su especialización, a su consideración de relevantes operadores jurídicos en el orden extraprocesal, y a la paz social y seguridad jurídica preventiva que supone su intervención como garantes de la legalidad.

La desjudicialización de competencias en los ámbitos señalados y su atribución a Notarios y Registradores de la Propiedad y Mercantiles, que constituye una de las más relevantes novedades de la reforma, supone, por otra parte, no sólo devolver a estos funcionarios públicos, al propio tiempo que profesionales del derecho, un protagonismo en esta materia que ya les había sido atribuido por la historia, sino también el reconocimiento de una titularidad que les corresponde por su propia naturaleza, en atención al desempeño de funciones de autenticación, notificación, documentación y garantía de derechos, lo que hace que el notario actual, en palabras de Rodríguez Adrados, no sea un mero fedatario público, sino que ejerce un oficio público en cuanto a su función certificante y autorizante, al propio tiempo que realiza un juicio de legalidad del acto en que interviene y de asesoramiento de los intervinientes, con sometimiento al control o revisión judicial.

A lo largo de los siglos IX al XII, en todos los países europeos y singularmente en Inglaterra, Francia, Alemania en Inglaterra, así como en España a partir del siglo XIII, se produce una evolución jurídica consistente en que una parte importante de las actuaciones negociales de JV se realizaban ante los notarios que estaban adscritos a los tribunales tanto laicos, como eclesiásticos. De forma especial, a partir del siglo XII, el conocimiento y resolución de una parte importante de supuestos de JV que se sustanciaban ante los jueces se atribuyó a los Notarios, que se configuran como el órgano por excelencia de la JV en la Europa del medioevo. 
La atribución de determinadas competencias en esta materia a los Registradores, se justifica asimismo en atención a su posición de titulares de una relevante función pública - que tiene su antecedente remoto en la actividad desarrollada por los empleados públicos encargados de los Registros existentes en derecho Romano - en virtud de la cual proceden a la calificación y valoración, conforme a la ley, de los actos en que intervienen, con sometimiento al control o revisión judicial

b) La redistribución de competencias asignadas al órgano jurisdiccional entre Jueces y Secretarios Judiciales. Se asume por el Proyecto, en este punto, la opinión al respecto de un sector relevante de la doctrina procesalística, al tiempo que se hace realidad en este ámbito, el reforzamiento de las competencias de los Secretarios, en el marco de la Administración de Justicia, como reconocidos expertos en Derecho Procesal, conforme a las exigencias de la reforma de la Ley Orgánica del Poder Judicial, de 23 de diciembre de 2003.

No parece excesiva la afirmación de que son los Secretarios Judiciales el Cuerpo de Funcionarios que en mayor medido han visto reforzadas sus competencias en la materia, al reconocérseles una potestad decisoria, de la que carecen en el momento presente, en los expedientes específicos que se les atribuyen, tanto en la futura Ley de JV, como en los expedientes de JV contemplados en otras leyes y que no sean propios de la competencia judicial.

La desjudicialización y la redistribución de competencias en el seno del órgano jurisdiccional, están llamadas a producir, en el futuro, una mayor agilización en el tráfico jurídico y una mayor eficacia en los mecanismos de la Administración de Justicia, sin que ello suponga un menoscabo de la garantía constitucional de tutela judicial efectiva de los derechos e intereses de los ciudadanos.

c) La configuración de un procedimiento unitario, común para Jueces y Secretarios Judiciales, fundamentado en el juicio verbal, conforme se afirma en el apartado III de la E. de M. y en el art.22, en lo que supone de superación de las fragmentarias e inconexas Disposiciones Generales contenidas en el Libro III de la Ley Procesal de 1881, dedicado a la JV y todavía vigente, así como la aproximación a las reglas y principios informadores propios de la jurisdicción contenciosa, sin por ello soslayar las peculiaridades y especialidades caracterizadoras de la JV. El nuevo procedimiento supondrá, en la práctica, un cambio de tendencia denunciado por Ramos Mendez al referirse a < ...una inflación galopante de procedimientos y su regulación en leyes sustantivas $>$.

d) El régimen de competencias compartidas entre Secretarios Judiciales por una parte y Notarios y Registradores de la Propiedad y Mercantiles, por la otra, genera la posibilidad del ciudadano de acudir de forma opcional a uno u otro profesional del derecho en estos supuestos, lo que otorga un mayor grado de libertad y de participación de los justiciables en la administración de la Justicia. 
e) La adecuada sistematización de procedimientos y su acotación objetiva a los ámbitos civil y mercantil, con arreglo a la tradicional clasificación de derecho privado, si bien la inequívoca existencia de actos de JV, en otros ordenes jurisdiccionales, como el penal, con la esterilización de incapaces al amparo del art. 156 del Código Penal, el laboral, con la conciliación prevista en los arts. 93 ss de la Ley de Procedimiento Laboral, o el constitucional, con la restricción judicial de derechos fundamentales, haría aconsejable la introducción de una cláusula que estableciese la aplicación supletoria de la normativa de la Ley de Jurisdicción Voluntaria.

f) La desregulación de procedimientos obsoletos y la reforma de los todavía útiles, en conexión con la actual realidad social.

\section{$\checkmark$ Propuestas de MeJora del TeXTO NORMATIVO: ESPECIAL REFERENCIA AL MENOSCABO DE GARANTÍAS EN EL PROCEDIMIENTO JUDICIAL Y A LA AUSENCIA DE RESERVA JURISDICCIONAL}

El posible menoscabo de garantías y a la ausencia de reserva jurisdiccional, constituyen, a mi juicio, los aspectos más discutibles de la reforma, por lo que deben ser objeto de una especial valoración, al efecto de su posible modificación en el curso del debate parlamentario, lo que redundaría, a mi entender, en una mejora del texto normativo.

La necesaria desjudicialización de competencias no justifica que se administrativice el procedimiento judicial y se menoscaben alguna de sus fundamentales garantías, como así sucede con las previsiones legales consistentes en:

a) la supresión del principio de contradicción

b) el carácter no preceptivo de la asistencia técnica de abogado

c) la supresión de los recursos.

La equiparación, en este punto, entre el procedimiento administrativo notarial o registral, en el que podría no requerirse la exigencia de tales garantías, y el procedimiento judicial, resulta ,a mi juicio, una previsión desacertada. Conforme se afirma en el Fundamento de Derecho $7^{\circ}$ de la STS de 22 de mayo 2000:

$<$ El que se admita la existencia de actuaciones de jurisdicción voluntaria atribuidas a órganos no judiciales, para las que tal denominación es harto discutible, no supone que cuando un juez o tribunal está llamado por ley a definir un derecho o a velar por él, sin que exista contienda entre partes conocidas y determinadas(artículo 1811 de la vigente LEC), su actuación no deba estar revestida de las garantías propias de la jurisdicción>. 
a) A la práctica desaparición del principio de contradicción se refiere el art. 7 PL del Título I, Capítulo II, relativo a las Disposiciones Comunes a todos los administradores de expedientes, al establecer que: < Cuando durante la tramitación del expediente surja una controversia entre los interesados que impida su continuación se procederá a su archivo, excepto los expedientes en que esté comprometido el interés de un menor o incapaz>.

Sin embargo, la contradicción previa y manifiesta, implícita o subyacente o sobrevenida, tiene o puede tener lugar en muchos procedimientos .Esta consideración encuentra su expresión más manifiesta en los supuestos de derecho de familia, en los que el propio rótulo del Capítulo segundo, del Titulo dedicado a la JV en Derecho de Familia, pone de relieve la existencia de la discrepancia: $<$ De la intervención judicial en los casos de desacuerdo conyugal y en la administración de bienes gananciales>. Parece pues que, al menos en estos casos, debería valorarse la conveniencia de su inclusión en el régimen especial previsto en los supuestos de menores e incapaces, si no se quiere incurrir en una contradicción con la propia realidad social y legal. Se trata, en definitiva de supuestos de discordancia sobre la fijación del domicilio conyugal, la contribución de un cónyuge a las cargas del matrimonio, el consentimiento para la realización de actos de administración y disposición de bienes comunes o su atribución a uno de los cónyuges en os casos previstos en la legislación sustantiva. Se trata de supuestos en los que por existir un grado de contradicción atenuada y en atención a su urgencia o a la necesidad de atender a una necesidad imperiosa, el Ordenamiento considera que no resulta ineludible que sean dirimidos por la vía del proceso contencioso.

Es frecuente, sin embargo, que la contradicción expresa, latente o sobrevenida, se manifieste asimismo en otra serie de supuestos como en: deslindes; nombramiento de defensor judicial ante posibles intereses contrapuestos entre menores e incapacitados y sus representantes, remoción de tutor o curador; impugnación de la validez del reconocimiento otorgado durante la minoría de edad o incapacidad del reconocido, una vez alcanzada la plena capacidad por el menor o incapaz; retorno de menores en supuestos de sustracción internacional; fijación del plazo para el cumplimiento de la obligación, ante la falta de acuerdo de las partes; nombramiento de tercer perito en contrato de seguro; auditoría de cuentas de los empresarios, declaración de ausencia; expediente de dominio de reanudación del tracto sucesivo, con inscripciones contradictorias, conforme al 201 LH; expedientes de liberación de gravámenes; revocación del auditor de cuentas designado por el Registrador Mercantil, en caso de oposición de los interesados; albaceazgo; nombramiento de contadores partidores dativos, en caso de desacuerdo entre los herederos, etc, y ello no debería sin embargo, en buena lógica, producir el archivo del expediente, cuando esta solución contradiga la naturaleza del acto y el fin que en el mismo se persiga o el acto tenga carácter coercitivo, conforme a la jurisprudencia del TS.. En caso contrario, podría producirse un menoscabo del principio contradictorio y una reducción drástica en la eficacia de la Jurisdicción Voluntaria, en aras de la rapidez. 
En todo caso, la supresión de la contradicción, que puede quizás resultar razonable en el procedimiento administrativo notarial o registral, no debería sancionarse respecto del procedimiento judicial, en el que audiencia y contradicción son principios que se complementan, que difícilmente se entienden el uno sin el otro, al tiempo que se configuran como básicos e inherentes a la naturaleza jurídica del propio procedimiento.

Por otra parte, cabe señalar que no hay sòlo meros interesados en los procedimientos de jurisdicción voluntaria, conforme se afirma en la E.de M III: $<$ Tampoco tiene lugar (en la jurisdicción voluntaria) el principio contradictorio, toda vez que la existencia de meros interesados en el procedimiento elude de antemano la presencia de partes....>, sino que, por el contrario, pueden existir también afectados, en expresión del T.C.,STC 124/2002,de 20 de mayo, o una pluralidad de interesados, con intereses diferentes, aunque convergentes, o simplemente divergentes, o con intereses contrapuestos, contrainteresados, conforme a la terminología utilizada por la doctrina italiana. Así en la STS citada se afirma

$<$ Si analizamos la actuación del presidente del TSJ en la tramitación y resolución de dicho recurso, se constata la existencia de los requisitos o notas propias del ejercicio jurisdiccional, apareciendo incluso una que, de ordinario, no concurre en otras actuaciones de jurisdicción voluntaria, cual es la contradicción>.

El ALJV de octubre de 2005 tenía en cuenta el nuevo perfil de la institución, que se había puesto de manifiesto en numerosos procedimientos específicos, en los que sin existir lesión de derecho subjetivo o interés legítimo, ni controversia relevante, aunque sí atenuada o debilitada, explícita o subyacente, el legislador había considerado que no existía causa de suficiente entidad como para ser dirimida en proceso contencioso, por lo que el desacuerdo o la contradicción se reconducía a un procedimiento de jurisdicción voluntaria. La nueva realidad legal encontraba su cauce en lo establecido en el artículo 18.2, conforme al cual:

< Salvo que la ley expresamente lo prevea, la formulación de oposición por algún interesado en el asunto no hará contencioso el expediente, ni impedirá la tramitación del mismo hasta su resolución, que surtirá los efectos que correspondan a tenor de su contenido, en tanto no sea revocada o modificada, en proceso declarativo promovido por persona legitimada>.

Por el contrario, la supresión de la contradicción en el actual PL, salvo cuando esté comprometido el interés de un menor o incapaz, supone aferrarse al viejo y superado esquema de una jurisdicción voluntaria estrictamente negocial. 
Por otra parte, no parece razonable que se ventile en el procedimiento la contradicción tan sólo cuando está comprometido el interés de un menor o incapaz y no en otros procedimientos en los que se prevé la intervención exclusiva del juez y que asimismo afectan al interés general, publico o social , a los que se hace referencia en el artículo 13.3, en el se señalan las materias de las que el Secretario Judicial no podrá conocer:

$<$....los expedientes regulados en otras leyes....... que tengan por objeto la condición o estado civil de la persona, o asuntos de Derecho de familia, menores o incapaces. Tampoco conocerán de los expedientes que afecten a derechos y libertades fundamentales, ni de aquellos que tengan por objeto materias sobre las que los interesados no puedan disponer libremente>.

Cabría preguntarse si no habría sido mas acertado mantener la posibilidad de contradicción en todos estos procedimientos en atención a la relevancia de su contenido y, en especial, en los propios de derecho de familia regulados de forma específica en el PL, en los que la discrepancia, controversia o conflicto es previo e inherente al expediente sustanciado, hasta el punto que se recoge en la propio nombre que se le otorga al procedimiento: De la solución de controversias en el ejercicio de la patria potestad y De la intervención judicial en los casos de desacuerdo conyugal y en la administración de bienes gananciales.

Como se observa al respecto en el Informe del CJPJ al A.,

$<$... la definición que vincula la JV al ejercicio pacífico de los derechos y que hace gravitar la diferencia con la jurisdicción contenciosa en el elemento negativo de la ausencia de controversia, no es válida para aquellos procedimientos que prevén incidentes de oposición, vías de impugnación o incluso la intervención del MF o de un defensor judicial, precisamente para abrir la vía a posibles discrepancias procedentes de sujetos distintos tanto del proponente como del decisor....

La artificiosidad que supone la supresión de la oposición, como era previsible, genera contradicciones en el seno del propio texto del Anteproyecto, sin necesidad de esperar a la crítica que, en buena lógica, generará su desafortunada inclusión en el texto prelegislativo. En este sentido, no parece muy coherente que se suprima el principio contradictorio al propio tiempo que se afirma que:

$<$ Se ha configurado un procedimiento un procedimiento general y básico para los expedientes administrados por Jueces y Secretarios Judiciales fundamentado en el juicio verbal...>, E. M.III; b) < se ha producido un reforzamiento de los principios dispositivo y de aportación de parte, una atenuación del dirigismo judicial y una 
aproximación de las posiciones de solicitantes, interesados o terceros> E.M III, pues en buena lógica procesal la conformación de estos principios favorece la posibilidad de que se genere contradicción c) y mucho menos que se llegue a afirmar en el apartado VI de la E. de M. que $<$ En la regulación del procedimiento al que deberán ajustarse Jueces y Secretarios Judiciales, se refuerza el principio contradictorio en el trámite de la comparecencia....> .

A propósito de la contradicción, se señala en el Informe del CGPJ:

$<$ Que la afirmación de la EM III: <.....Tampoco tiene lugar, en la JV, el principio contradictorio..........se ven matizadas en la propia EM VI en relación con los "expedientes administrados por Jueces y Secretarios Judiciales” para los que si rige el principio de la contradicción en el trámite de la comparecencia. Si a esto se añade la potencial contradicción procesal que va implícita en el trámite de audiencia a los interesados, se ve con mayor claridad que la ausencia de contradicción cede como elemento diferenciador con la jurisdicción contenciosa> (pg.32)

Conclusión Tercera: <La ausencia de contradicción o la solución pacífica de controversias, dejan de ser los elementos que tradicionalmente han diferenciado la JV de la contenciosa, incrementando la reforma las posibilidades de contradicción sin que ello necesariamente suponga la alteración de los términos del procedimiento>.

Por su parte, en el Informe del Consejo Fiscal se afirma:

$<$ Por su parte, el A. utiliza como nota definitoria de los expedientes de jv. la ausencia de contraposición entre partes, aunque tal fuera conveniente matizar esta afirmación para dar cabida a aquellos casos en que la contradicciones es muy leve, ya que en muchos casos de jv. - fundamentalmente en materia de personas y familia - se supone latente una controversia aunque no tenga una entidad suficiente para ser dirimida en un proceso contencioso>. (p.7)

En definitiva, un procedimiento, que se fundamenta en el juicio verbal, conforme al art. 22, en el que se potencia, con carácter general, el principio de audiencia, y los principios dispositivo y de aportación de parte, en numerosos supuestos, en el que se aproximan las posiciones de solicitantes, interesados y terceros no interesados, y se establece que la resolución no producirá efectos de cosa juzgada material, goza de las suficientes garantías como para prever la posible contradicción, que no lesión de derecho subjetivo o interés legítimo, que pueda generarse en la sustanciación del expediente.

Cabe afirmar, por otra parte, que al afirmarse en el art. 7 que no toda controversia determinará la terminación del expediente, sino sólo cuando la contraposición <impida 
su continuación> habrá que proceder a valorar entidad de la oposición al efecto de decidir el archivo del expediente. En este sentido, si cabe afirmar que, si bien hubiera sido deseable referirse al carácter relevante de la controversia o incluir la fórmula recogida en el A.2005, al menos en el Proyecto de Ley se ha dado un pequeño paso adelante respecto a lo previsto en el actual art. 1817 LEC 1881.

Dado que la ausencia de contradicción o el ejercicio pacífico de los derechos han dejado de ser la nota esencial de la JV, ha de considerarse superada la definición de la misma que la vincula a estos elementos, tanto en la propia realidad social como jurídica Suprimir ex lege la existencia de la contradicción, no sólo supone ponerse un velo ante la realidad manifestada en las frecuentes alegaciones, incidentes, mutaciones o vicisitudes que suelen producirse en la tramitación de un expediente, sino que menoscaba la propia esencia del procedimiento judicial, cualquiera que sea su objeto. Al menos debería incluirse en la definición legal el matiz consistente en la ausencia de contraposición relevante entre los interesados.

b) El carácter no preceptivo de la asistencia técnica de abogado.

No resulta justificado, a mi juicio, el radical cambio de criterio legislativo en este punto, consistente en suprimir la intervención preceptiva de abogado. La propensión a equiparar o aproximar, también en este aspecto, procedimientos de jv.de distinta naturaleza y atribuidos a distintos titulares de competencia, en aras de la simplificación, de la disminución de formalidades y del coste del expediente, puede suponer, sin embargo, en determinados supuestos, una regresión en el reforzamiento de las garantías de los intervinientes.

En el A. de 2005, la representación de los interesados en el procedimiento se había regulado con un criterio análogo a la regulación vigente. El interesado debía ser dirigido por abogado, salvo en casos de conciliación, expedientes de culantía inferior a dos mil cuatrocientos euros, para presentar la solicitud en expedientes que tengan por objeto la adopción de medidas urgentes o que deban instarse en plazo perentorio, expedientes de reconocimiento de filiación extramatrimonial, y para la intervención de los interesados, distintos del solicitante, siempre que no tenga por objeto formular oposición.

Pues bien, el reforzamiento en el PL de los principios de audiencia, dispositivo y aportación de parte, la atenuación del dirigismo judicial, la posibilidad de la práctica de todo tipo de pruebas, lo que redundará en una superación de la verosimilitud a la que se encuentran abocadas, en ocasiones, las tradicionales informaciones, acreditaciones y justificaciones, previstas en la regulación vigente, unido todo ello al reconocimiento expreso de la posibilidad de contradicción y de recursos, en los procedimientos en los que se vean afectados intereses de menores o incapaces, al propio tiempo que supondrá una mejora en las garantías de los intervinientes y en la dialéctica entre los solicitantes, interesados - en especial en aquellos supuestos en que se manifieste un interés contrario o divergente del solicitante - o terceros no interesados, implicará, en determinados procedimientos, una mayor dificultad y complejidad procesal. 
Por otra parte, la trascendencia económica de los intereses en juego, en ocasiones, la necesidad de razonar con criterios de lógica jurídica la utilidad o conveniencia de adoptar una u otra toma de postura, en otras vicisitudes, la proposición o práctica de pruebas, o bien las propias tensiones que generan las controversias en el ejercicio de la patria potestad, las relaciones de menores con el progenitor que no sea titular de la patria potestad o con parientes o allegados, o las divergencias relativas a la administración de los bienes de menores o incapaces o en la administración de bienes gananciales en el seno de la comunidad conyugal etc., parecen razones suficientes para que se reflexione sobre este punto, al efecto de distinguir entre aquellos supuestos en los que la previsible ausencia de dificultad técnica no hace necesaria o conveniente la preceptiva asistencia letrada, y aquellos otros en los que la posibilidad de contradicción o recursos prevista en los propios procedimientos, como sucede en los casos de menores o incapacitados o la existencia de una discrepancia o contradicción atenuada a priori, lo que tiene lugar en los procedimientos en materia de familia, hacen aconsejable la obligada intervención de un abogado. Podría incluso resultar aconsejable el establecimiento de la preceptiva intervención de abogado, con carácter general, en todos aquellos procedimientos cuya titularidad se atribuya a los Jueces.

Cabría asimismo plantearse en que medida resultaría apropiada el carácter preceptivo de la asistencia técnica de abogado en procedimientos tramitados ante los S.J que pueden revestir una especial complejidad, como los expedientes de dominio y de liberación de cargas y gravámenes, la fijación del plazo para el cumplimiento de las obligaciones, el albaceazgo, o la liquidación de averías.

Parece asimismo razonable argumentar que en atención a lo establecido en el art. 22 del PL < La comparecencia se sustanciará por los trámites del juicio verbal con las siguientes especialidades.....>, resultase preceptiva la intervención de abogado y procurador, conforme al criterio establecido al efecto para el juicio verbal, en los arts. 23 ss LEC, en materia de primera instancia y apelación.

c) La supresión de los recursos podría resultar razonable en el ámbito del procedimiento administrativo, pero no en el procedimiento judicial, en el que la contradicción y los recursos y, por ende de la doble instancia, con carácter general, parecen inherentes a su propia naturaleza. La Jurisdicción Voluntaria, no debería identificarse con supresión o disminución de garantías, plazos y formalidades, en aras de la celeridad, pero en detrimento de la tutela judicial y la seguridad jurídica, características de toda actuación judicial.

En materia de recursos, a mi juicio, hubiera sido más procedente el mantenimiento de los previstos de reposición, apelación y queja, según se establecía en el ALJV de octubre de 2005, y en la Ley de Enjuiciamiento Civil. Contra las resoluciones definitivas dictadas por el Juez, se preveía un recurso de apelación ante la Audiencia Provincial y contra los decretos dictados por el Secretario, en los expedientes de su competencia, cabría un recurso ante el Juez titular del mismo Juzgado, 
o ante el que correspondiese en caso de Servicio Común, que se sustanciará por los trámites y con los requisitos del recurso de reposición, regulado en la LEC (art. 19,2).

No parece razonable, a mi juicio, que la resolución del juez pueda ser apelada (art. 24) y, sin embargo, el decreto del Secretario sea firme desde el mismo momento en que se dicte(art. 24.1). Por otra parte, la disposición contenida en el art. 24.1, conforme a la cual $<$ Contra las resoluciones dictadas en los procedimientos de j.v. no cabrá recurso alguno>, entra en contradicción con el tenor del art. 13.3: $<$ Corresponderá también al Secretario Judicial la tramitación y resolución definitiva, sin perjuicio de los recursos que procedan, en los expedientes de jurisdicción voluntaria regulados en otras leyes que no tengan por objeto la condición y estado civil de la persona, o asuntos de derecho de familia, menores o incapaces....... , atinente a la competencia objetiva, que reproduce el texto del art.5.2 del Anteproyecto de octubre de 2005, en el que se preveía un recurso contra la resolución definitiva del Secretario, al igual que en el art. 19.2, del mismo texto legal .

Resulta todavía más sorprendente la previsión del art. 24.1, si se tiene en cuenta que en el espíritu y en la letra de las disposiciones legislativas atinentes a la competencia de los Secretarios se prevé la posibilidad de recursos contra los decretos dictados por los Secretarios, incluso con referencia específica a la Jurisdicción Voluntaria. Así conforme al artículo 456.3 b) y 4, correspondiente a la reforma de la Ley Orgánica del Poder Judicial de 23 de diciembre de 2003, se afirma que <Los Secretarios Judiciales, cuando así lo prevean las leyes procesales, tendrán competencia en la materia de jurisdicción voluntaria, asumiendo la tramitación y resolución de los expedientes, sin perjuicio de los recursos que quepa interponer .... La resolución que se dicte para poner término a la resolución del expediente recibirá la denominación de decreto>. En el Proyecto de Ley Orgánica, aprobado en Consejo de Ministros de 16 de diciembre de 2005, por el que se adapta la Legislación procesal a la Ley Orgánica 6/1985, de 1 de julio del Poder Judicial, se establece, en la propuesta de reforma correspondiente al art. 454 bis de la LEC que «Cabrá interponer recurso de revisión .... contra los decretos (dictados por los Secretarios) que pongan fin al procedimiento o impidan su continuación......».

Por otra parte, en la única previsión legal del PL. respecto del decreto dictado por el SJ, contenida en el art. 25.3, relativo a la Caducidad del expediente, se establece que: <Contra el decreto que declare la caducidad sólo cabrá recurso de revisión>. Pues bien, resulta sorprendente que se admita un recurso contra el decreto del Secretario en materia de caducidad y no contra los decretos que ponen fin al procedimiento de JV.

Parece pues apropiada, ante la relevancia de los procedimientos sustanciados ante el Secretario, la previsión de un recurso de revisión ante el Juez, con carácter general o al menos en procedimientos específicos como pueden ser la fijación de un plazo para el cumplimiento de las obligaciones, o el albaceazgo, así como el mantenimiento de los recursos de apelación y queja en 
los procedimientos judiciales. Parece por todo ello razonable proponer que se proceda a valorar, de nuevo, la supresión de la doble instancia que supone el recurso, al efecto de una posible reconsideración.

Por lo que se refiere a la ausencia de reserva jurisdiccional, cabe señalar lo siguiente: La afirmación contenida en la Exposición de Motivos, apartado III, párrafo $2^{\circ}$, conforme a la cual: <Tal como aparece concebida en la presente ley, la jurisdicción voluntaria encuentra su amparo en el art. 117.4 de la Constitución, como función expresamente atribuida a los Juzgados y Tribunales en garantía de derechos que se ha considerado oportuno sustraer de la tutela judicial que otorga el proceso contencioso, claramente amparado en el art. 117.3>, supone una toma de postura doctrinaria, en una cuestión sometida a debate en la doctrina europea, así como contraria a la más reciente Jurisprudencia del Tribunal Supremo, que en sentencia de 22 de mayo del año 2000 argumenta que:

$<\ldots$ no se puede afirmar que en la denominada jurisdicción voluntaria, los jueces y tribunales no están ejerciendo potestades jurisdiccionales, con independencia que de ulteriormente quepa sobre lo mismo otro proceso contradictorio y, en consecuencia, esas potestades quedan amparadas por el art. 117.3 de la Constitución...............Las demás funciones, que el art. 117.4 de la CE. permita que una Ley atribuya a juzgados y tribunales en garantía de cualquier derecho, son aquéllas que, a diferencia de las denominadas de jurisdicción voluntaria, no comportan protección jurisdiccional de derechos o intereses legítimos, como en los supuestos de participación de jueces o magistrados en Jurados de Administración Forzosa o en la Administración Electoral....>.

Por otra parte, la exclusión de la jurisdicción voluntaria del núcleo esencial ,indisponible y excluyente de funciones que conforman la potestad jurisdiccional de los jueces, previsto en el art.117.3, y su inclusión en las funciones de los jueces en garantía de derechos, conforme al art.117.4, respecto de las que no existe una reserva de jurisdicción, comportaría la posibilidad de traspaso, en un futuro, de las funciones relativas a menores, incapacitados, discapacitados, desvalidos, materias indisponibles o atinentes a intereses públicos, a otros operadores jurídicos que, en un momento determinado, fuesen considerados más idóneos, lo que, a mi juicio, no sería asumible en el actual marco constitucional. Lo que sí cabría afirmar es que las competencias atribuidas a los jueces en el ámbito de la jurisdicción voluntaria se incluyen, en atención a la materia de que se trate, en los párrafos tercero o cuarto del art. $117 \mathrm{CE}$. 
En el sentido aludido de inclusión de los actos de j.v. en los párrafos 3 y 4 del art. 117, se pronuncia el Informe del Consejo Fiscal: <........por ello la Ley se esfuerza en distinguir entre los actos de jurisdicción voluntaria de inequívoca naturaleza jurisdiccional - reservados a los jueces según los artículos 117.3 y 4 CE y 2.2 LOPJ - y aquellos que carecen de tal carácter y pueden, por ello, ser encomendados a otros órganos de la Administración Civil del Estado con todas las garantías> si bien, a mi juicio, cabría matizar que: a) el A., el PL no distingue, como parece lo apropiado, entre actos de jv. jurisdiccionales y actos de jv. que carecen de tal carácter y si lo hace el Informe del Consejo Fiscal. Es decir que, efectivamente, el texto legal debería esforzarse en distinguir entre actos de JV jurisdiccionales y no jurisdiccionales, pero no lo hace en la práctica, y quien si se esfuerza en conformar esta distinción es el Consejo Fiscal, y b) los actos de JV jurisdiccionales se enmarcan en el ámbito del 117.3, y los que no tienen esta naturaleza y no obstante se atribuyen a jueces en garantía de derechos, son los propios del 117.4.

La potestad jurisdiccional tiene una naturaleza heterocompositiva, que excede el marco de la resolución de conflictos a través de un proceso contencioso. El objeto de numerosos procedimientos de jurisdicción voluntaria, incoados de oficio o a solicitud de interesado, consiste en constituir o dirimir derechos, con transcendentales efectos, lo que requiere una labor de enjuiciamiento que exigirá la subsunción de los hechos en las normas jurídicas sustantivas y procesales que se consideren aplicables, la admisión y valoración de los medios de prueba que se presenten o se practiquen de oficio, y el pronunciamiento de una resolución motivada, que se ejecutará, en tanto que no sea revocada o modificada en el marco de la propia jurisdicción voluntaria o en proceso declarativo promovido por persona legitimada. En definitiva, a mi juicio, la actuación del juez en este ámbito, y en determinadas materias, es la propia de la función jurisdiccional prevista en el art. 117.3 y, por ello, las competencias que al efecto se le reconocen no son atribuibles a ningún otro operador jurídico.

En este sentido parece apuntar el Informe del CGPJ al A. cuando afirma: $<$....sin la nota de exclusividad del apartado 3 del art. 117, el problema queda reducido a una opción del legislador, que podrá sustraer a la intervención judicial lo que constityen manifestaciones de carácter constitutivo - negocial, autorizaciones, aprobaciones u homologaciones....... >, < ........al considerar el encaje constitucional de los procedimientos de JV en el apdo.4 del art.117, la intervención judicial no reviste la nota de exclusividad, y el ámbito competencial de los Jueces en esta materia se reduce a los asuntos de derecho de personas y de derecho de familia...... . 


\section{Reflexiones Críticas Sobre Cuestiones Varias}

a) La utilización de expresiones como <administradores o gestores de expedientes $>$ o de $<$ la administración del derecho privado $>$, E.M. III y V, resulta apropiada en el ámbito administrativo notarial y registral, pero inapropiada en referencia al órgano judicial. La consideración de forma indistinta a todos los titulares de competencias en la materia, Jueces, Secretarios, Notarios, Registradores u otro funcionario designado, art. 1 ALJV, supone una pretensión indisimulada de adninistrativizar la jurisdicción voluntaria, que solo produce confusionismo, al crear una categoría novedosa y heterogenea, que pone en el mismo plano a operadores jurídicos que no lo están en el marco del Ordenamiento, ni por la naturaleza jurídica de sus actuaciones ,ni por el grado de independencia e imparcialidad de cada uno de ellos en relación con los ciudadanos y con los otros órganos del Estado. Como se afirma al respecto en el Informe del CGPJ, a propósito de la conciliación: <....el fundamento por el que se atribuye la competencia a los miembros del Poder Judicial ha de estar en las garantías que proporciona su estatuto-con independencia de las singularidades del régimen de los Jueces de Paz- y que no comparte con otros servidores públicos.....> (p.65).

En el sentido apuntado de crítica a la denominación se manifiesta asimismo el CGPJ en su Informe al A., cuando afirma:<...lo que el A. denomina “ administradores del expediente" - parece que intentando encontrar una denominación genérica a todos ellos - constituye una denominación poco afortunada dado que los procedimientos de JV no son, en puridad, susceptibles de administración sino de tramitación y resolución, que es, por otra parte, aquello en que consiste la actividad de estos sujetos, sin olvidar que el aspecto de administración o de gestión de los expedientes de JV - al que también se refiere la EM V - no es el que mejor se corresponde con la función que ejercen los miembros del Poder Judicial>. < El A. denomina "administrador del expediente" a las autoridades y funcionarios a los que la ley, ésta u otra, designe para conocer y resolver los expedientes de JV (art.2.1), denominación que por ir asociada a la idea de gestión se considera inadecuada, tanto referida a la actividad que se realiza, como, en particular, a la función judicial>.

Se deja, por otra parte, la puerta abierta a la intervención de "otro funcionario designado" art.1.2. "Se considerarán expedientes de jurisdicción voluntaria todos aquellos en que se solicita la intervención de un Juez, Secretario Judicial, Notario u otro funcionario designado para la administración o tutela de cuestiones de derecho civil y mercantil en las que no exista contraposición entre los interesados", lo que refuerza la tendencia a la "administrativación” de estos procedimientos,con la intervención de funcionarios públicos, respecto de los cuales parecería razonable que se recogiese al menos la previsión relativa a la condición de profesionales del derecho de los futuros "administradores". 
En relación, en definitiva, con la terminología referida a la JV, cabe señalar que, en mi opinión, la más adecuada, en el ámbito judicial, se corresponde con la utilización de los vocablos acto, procedimiento y expediente. Cabría afirmar, en síntesis que, previsto en la disposición sustantiva, el acto de jurisdicción voluntaria y atribuida su titularidad a un Juez o un Seretario Judicial, se promoverá por persona legitimada o de oficio un procedimiento, en el curso del cual se procederá a la tramitación de un expediente. Por otra parte, parecen más apropiadas las expresiones < conocimiento del expediente>, que gestión o administración del expediente $\mathrm{y}<$ titular encargado del expediente $>$ que administrador del expediente.

La reiterada utilización, no obstante, en el PL de la expresión <asunto o asuntos de j.v.>, ej. D.A.1 ${ }^{\text {a }}$, propia del proceso contencioso, no parece la mas apropiada en el marco de la JV, ni encaja bien, por otra parte, con la pretendida configuración de la JV en el ámbito administrativo.

b) Desde el sector de la discapacidad, representado por el CERMI, Comité español de representantes de personas con discapacidad, se ha solicitado que :a) Se articule el procedimiento de JV previsto en el art.156 del Código Penal, relativo a la autorización judicial de la persona incapaz que adolezca de grave deficiencia psíquica; b) Se regule la autorización judicial para imponer tratamiento médico forzoso a los enfermos psíquicos y c) Se valore la conveniencia de que la autorización judicial para el internamiento de personas que padecen trastornos psíquicos, se tramite a través de un procedimiento de JV.

En la Memoria Justificativa del A. de 2005 se afirma que < la Ponencia tras una profunda reflexión consideró que no es un expediente de JV el procedimiento adecuado para tomar tan importante medida, cuando en los supuestos en cierto modo similares, de incapacitación, se acude al procedimiento contencioso....>, solución que ha mantenido en estudios anteriores. Ahora bien, la no regulación de un procedimiento específico, que se justificaría por la singularidad del presente supuesto, y el silencio al respecto en la Memoria y Exposición de Motivos del PL, exigen una toma de postura en la futura Ley, que debería valorar de forma especial la opinión de los colectivos más directamente afectados. La segunda propuesta del CERMI ha sido asumida en el PL, al articularse el correspondiente procedimiento, del que ya he dado cuenta en el capítulo dedicado a las Novedades del Proyecto. La tercera propuesta es un claro reflejo del carácter variable y fluido entre ambas esferas de la legislación, manifestado en instituciones como los alimentos provisionales, la incapacitación por locura o el internamiento de personas con trastornos psíquicos que se tramitaron por medio de procedimientos de JV antes de pasar a la esfera contenciosa. En el supuesto del internamiento el trasvase se materializó con su inclusión en la LEC 2000. A mi juicio, si se mantiene la esterilización en el marco de la JV, con mayor razón debería considerarse de naturaleza voluntaria el internamiento, lo que redundaría por otra parte en una mayor armonización del sistema. 
c) No parece apropiada la inclusión en una ley procesal un capítulo relativo a expedientes administrados por Notarios y Registradores, aunque tan sólo contenga dos artículos referidos a la competencia y al procedimiento, ni un capítulo de Disposiciones Comunes a todos los administradores de expedientes de jurisdicción voluntaria, en el que se contiene, entre otros, un artículo sobre los medios de prueba que se propongan durante la tramitación del expediente.

En todo caso, en relación con las Disposiciones Generales, parece que procedería incluir un párrafo en el que se estableciese que los titulares de competencias en materia de JV deberían actuar conforme a lo previsto en la Ley de JV, sin perjuicio de lo que, con carácter especial, dispongan otras normas.

d) Resulta sorprendente que en la definición legal de la Jurisdicción Voluntaria, contenida en el artículo 1.2, se haya suprimido la referencia a la posibilidad de que el procedimiento se incoe de oficio, en contra de lo previsto en el vigente artículo 1811 de la LEC de 1881, en el Texto de octubre de 2005 y de lo establecido en diversos procedimientos específicos como la tutela, la adopción o el acogimiento .Incluso en alguno de los procedimientos, como el de Protección del patrimonio de las personas con discapacidad, sólo puede ser instada su incoación por el Ministerio Fiscal.

Conforme se afirma en el Informe del Consejo Fiscal:

< el art.3 limita la legitimación a los titulares de derechos o de u interés legítimo sobre la materia que constituya su objeto, por lo que sería conveniente incluir entre los sujetos legitimados al MF ya que, en ocasiones, el Ordenamiento le encomienda la obligación de promover el expediente como, por ejemplo, en materia de tutela, ausencia o protección del patrimonio de las personas con discapacidad>

Por lo que respecta a la intervención del Ministerio Fiscal, no resulta acertada, a mi juicio, la supresión de la referencia expresa, que se contiene en el actual art. 1815 y se recogía en el art. 7.2 del A. de 2005, relativa a su preceptiva actuación cuando la solicitud promovida afecte a intereses públicos.

En relación con los demás aspectos referidos a la posición e intervención del Ministerio Público en los procedimientos de JV., cabe destacar la positiva valoración realizada al respecto en el Informe del Consejo Fiscal.

e) Hubiera sido deseable que la afirmación genérica, ya citada, contenida en la E.M. III, relativa al < reforzamiento, en los procedimientos cuyo conocimiento y resolución se atribuyen a Jueces y Secretarios Judiciales, de los principios dispositivo y de aportación de parte,una atenuación del dirigismo judicial,y una aproximación de las posiciones de solicitantes, interesados y terceros>, hubiera sido matizada en el sentido de distinguir entre: 
i) aquellos supuestos en que el procedimiento se incoa a solicitud del interesado o de oficio, en atención a que su contenido afecta al interés publico, general o social, o a menores o incapacitados, en el que rige el impulso de oficio, con todas sus consecuencias, diferenciado del impulso procesal que se materializa en providencias de los Jueces y diligencias de ordenación de los Secretarios, en el sentido de que el Juez no está vinculado ni a la aportación de hechos, ni a la proposición de pruebas realizada por los intervinientes,sino que tiene la facultad, al propio tiempo que obligación de proceder a la práctica de todos los medios de prueba y diligencias necesarias o útiles para formar su convencimiento. A este impulso de oficio se refiere el art. 22.4 del PL, y

ii) aquellos supuestos, iniciados a solicitud del interesado, sin que esté en juego interés público, general o social, ni intereses de menores o incapacitados, en los que el procedimiento no se atendrá ,o lo hará de forma atenuada, al principio del impulso de oficio, sino que se conformará con arreglo a los principios dispositivo y de aportación de parte.

En el sentido expresado se pronuncian asimismo el Informe del CGPJ y el Dictamen del Consejo Fiscal.

f) Debería introducirse en el capitulo relativo a Disposiciones Comunes, una cláusula en la que se estableciese el carácter supletorio de su articulado, en relación a las actuaciones de JV reguladas en otras leyes, en lo que no se opusiesen a las normas específicas reguladoras de las actuaciones de que se trate.

\section{EN TORNO AL PROCEDIMIENTO COMÚN A JUECES Y SECRETARIOS JUDICIALES: PRINCIPIOS INFORMADORES Y REGLAS DE PROCEDIMIENTO}

Manifestaciones positivas de la nueva regulación del procedimiento pueden ser consideradas las siguientes: El acercamiento entre ambas jurisdicciones genera, un aumento de las garantías de los justiciables y la eliminación de determinadas disfunciones y reglas contrarias a la armonización del sistema, derivadas de una regulación diferenciada, por ejemplo, en materia de días y horas hábiles (art.1812 LEC 1881), salvo en materia de Derecho Marítimo, o de modificación de oficio de las providencias o autos no definitivos (ART.1818 LEC 1881). Se refuerza el principio de audiencia (art. 22,2 $2^{\mathrm{a}}$ ) y la participación activa de solicitantes e interesados y terceros no interesados en la comparecencia. Se establece que el desarrollo de la comparecencia se registre en soporte apto para la grabación del sonido y de la imagen, de conformidad con lo dispuesto en la LEC (art. 22.5). Se dispone la remisión a lo previsto en la LEC en materia de cumplimiento y ejecución de resoluciones (art. 26) y, con carácter supletorio, en todo lo no previsto de forma expresa (art. 12) y se resuelven de forma satisfactoria las instituciones de la acumulación de procedimientos y la litispendencia. 
Se opta por regular la sustanciación del expediente, de forma preferente, en el marco de los principios de oralidad, concentración e inmediación. Asimismo supone un avance la previsión de que la solicitud pueda presentarse empleando un impreso formalizado, que se facilitará por la Oficina Judicial, al que se acompañaran los documentos que el promovente considere de interés y las copias necesarias en función del número de interesados.

Se prevé la práctica de todo tipo de pruebas (art. 5) en sustitución de las tradicionales acreditaciones, justificaciones o informaciones (arts. 1816 y 2111 LEC 1881. Ahora bien, tal y como se señala en el Informe del CGPJ: < La previsión legal relativa a la prueba resulta deficiente, Frente a la limitación que supone circunscribir al denominado administrador a admitir o inadmitir los medios de prueba que se le propongan (art.5.1), y a la ausencia en el articulado de una referencia a la libertad de forma (a la que se aludía de forma genérica en el art. 14 del A. de 2005), en la MJ se afirma, por el contrario, que < el administrador podrá completar las pruebas que considere oportuno pedir $>$, y que < se prevé la admisión ,sin necesidad de solicitud, ni otra solemnidad alguna, de los documentos que se presentaren y de las justificaciones o pruebas que se ofrecieren..... > Pues bien, el problema se deriva, a mi juicio, del hecho de que en el texto de la MJ se reproduce, sin citarlos, el tenor literal de dos artículos, el 14 y el 16, contenidos en la regulación del A. de octubre de 2005, sin que ello se refleje en el contenido del articulado referido a la actividad probatoria, lo que genera confusión. Por otra parte, si bien parece justificada la ausencia del principio preclusivo sobre admisión y práctica de pruebas (art. 5.1) en los procedimientos que se rigen por el principio de oficialidad, no parece apropiada la extensión de esta regla a los procedimientos que se rigen por el principio de justicia rogada.

La regulación legal de la cosa juzgada no resulta satisfactoria, dado que la dicción legal puede dar lugar a confusión. En el ámbito de la cosa juzgada formal, parece claro que las resoluciones, dictadas en todo tipo de procesos y procedimientos, que devengan firmes resultan inimpugnables, por lo que producen efectos de cosa juzgada formal, a ello se refiere el art. 207 LEC cuando afirma que $<$ transcurridos los plazos previstos para recurrir una resolución sin haberla impugnado, quedará firme y pasada en autoridad de cosa juzgada.......... ,lo que no obsta, para iniciar un proceso contencioso ,con independencia de que hayan variado o no los sujetos, el objeto o las circunstancias o presupuestos propios del procedimiento voluntario precedente y sin que ello deba entenderse, en modo alguno, como una impugnación de la resolución dictada en el marco de la jv.

Sucede, sin embargo, que el art. 23.2, puede generar confusión y cabe interpretar que entra en contradicción con el art. 2.2, al negar efectos de cosa juzgada al auto del Juez y al decreto del Secretario y no distinguir entre cosa juzgada formal, que sí se produce respecto de las resoluciones firmes en el marco de la jv., y cosa juzgada material, que asimismo se produce, a mi juicio, en su efecto negativo, en el 
ámbito de la propia JV, cuando se afirma en el propio art. 2. 2 que < Resuelto un expediente de JV. por cualquier administrador ,no podrá iniciarse otro expediente sobre idéntico objeto y entre los mismos interesados $>$, y no se produce, por el contrario, en su efecto negativo, fuera del ámbito de la propia jv., lo que se prevé en el art. 2.3, al disponerse que $<$ La resolución de un expediente de jv. no impedirá la incoacción de un proceso judicial con el mismo objeto>

En definitiva, las resoluciones de jv. no comportan efectos de cosa juzgada material fuera del ámbito de la propia jv., pero sí en este ámbito., en sus efectos negativo y positivo. Cabría afirmar, por su parte, en relación con éste último, que cualquier órgano jurisdiccional quedará vinculado en cualquier proceso o procedimiento, y ello encajaría en el denominado efecto positivo de la cosa juzgada material, por el contenido dispositivo de la resolución adoptada en el expediente de jv., siempre que ésta no se cuestione en un proceso ordinario, en cuyo caso el juez no estará vinculado, en medida alguna, por lo decidido en el procedimiento de jv. Negar efectos de cosa juzgada material a la jurisdicción voluntaria, en su propio marco, introduciría a mi juicio, una peligrosa variable, que sólo generaría inseguridad jurídica a los justiciables y al propio funcionamiento de la Administración de Justicia.

Lo que si sucederá, en ocasiones, es que en la práctica, la resolución del expediente habrá producido los correspondientes efectos, y no cabrá la revocación de su contenido, así por ejemplo, cuando el Juez ha autorizado al tutor para proceder a la venta de los bienes del menor, incapacitado o persona con discapacidad y la venta se ha producido, o el Juez ha autorizado una intromisión legítima en el ámbito del honor, intimidad personal y familiar o propia imagen del menor o incapaz y la actuación se ha realizado, o el Juez ha autorizado el tratamiento médico a una persona con trastornos psíquicos y la atención clínica ha tenido ya lugar , o el Juez ha autorizado la extracción de un órgano de un donante vivo y ésta se ha producido, o cuando verificado el nombramiento del defensor judicial de un menor o incapacitado, el defensor ha procedido ya a litigar en su representación, o cuando la subasta judicial no ejecutiva realizada ante Secretario Judicial ha concluido mediante la adjudicación de los bienes subastados, o cuando el Notario ha procedido ya a la apertura y lectura del testamento cerrado, o cuando el Registrador Mercantil ha convocado la Asamblea General y ésta se ha celebrado.

\section{SUSTANCIAL MODIFICACIÓN DEL MARCO COMPETENCIAL}

La reducción de las competencias de los Jueces, la configuración institucional de Notarios y Registradores de la Propiedad y Mercantiles como órganos o agentes de JV, la redistribución de competencias residenciadas en el órgano judicial entre Jueces y Secretarios Judiciales y la previsible atribución en 
el futuro de competencias a otros funcionarios de la Administración del Estado, constituyen el cambio más visible de entre los que conforman el nuevo perfil de la institución. Sería aconsejable, a mi juicio, en esta línea de sustancial modificación de criterio legislativo, aprovechar la oportunidad que supone la reforma para deslindar, con vocación de permanencia, entre:

a) Un ámbito judicial de competencias, con reserva jurisdiccional, conforme al art. 117.3 CE, referido a derecho de personas, derecho de familia (materias que se atribuyen a la competencia judicial en el art.13 del PL), al que deberían añadirse, de forma expresa, las actuaciones que tengan por objeto, derechos y libertades fundamentales, materias que afecten a menores o incapaces o sobre las que los interesados no puedan disponer libremente, y aquéllas otras en las que esté en juego un interés público.

b) Un ámbito de competencias residenciado en el órgano judicial, en garantía de derechos, atribuible a Jueces y, a Secretarios Judiciales, conforme al art. 117.4 CE.

c) Un ámbito administrativo de competencias, atribuible a Notarios y Registradores de La Propiedad y Mercantiles, también en garantía de derechos, conforme a los arts.149.1.8 y 9.3 CE., en el que se incluyen, como así se ha hecho en el Proyecto de Ley, un amplio número de procedimientos que, atribuidos en su momento a los jueces, en atención a decisiones de oportunidad, tradición histórica, orden público u ordenación del sistema, han sido objeto de traslado e imputación a estos operadores jurídicos, o bien en consideración a la propia naturaleza de las actuaciones o bien debido a criterios actuales de política legislativa.

En relación con dicho ámbito administrativo, si bien el término Jurisdicción, entendido en sentido técnico, debería reservarse en puridad para hacer referencia a los titulares de potestad jurisdiccional, Jueces y Magistrados, así como otros órganos expresamente previstos en la Constitución, por lo que la denominación más apropiada para referirse a la titularidad de estos profesionales seria: $<$ Competencias notariales o registrales en garantía de derechos $>\mathrm{y}$, en este sentido me he pronunciado en numerosas ocasiones, creo que resulta asimismo razonable argumentar, situándose dentro de la propia lógica interna que opera en el interior del sistema que se pretende modificar, y que, en definitiva, determina su progreso, que la asimilación de las actuaciones propias de los distintos operadores jurídicos en el marco exclusivo del ejercicio pacífico de los derechos, unido al hecho del reconocimiento de competencias en la materia a estos operadores jurídicos en distintas etapas históricas, podrían resultar elementos a valorar en orden al mantenimiento de la terminología utilizada en el texto prelegislativo.

La posibilidad de atribuir la competencia para conocer y resolver expedientes de JV < ...a otro funcionario designado - en la misma posición que se otorga al Juez, Secretario Judicial, Notario y Registrador - para la administración o tutela de cuestiones de derecho civil o mercantil en las que no exista contraposición entre los interesados>, conforme a los artículos 1.2 y 13.2, supone introducir una 
cláusula genérica que podría materializarse en el nombramiento de funcionarios, sin más especificaciones, a los que se atribuyese la titularidad en el futuro en supuestos de JV. Se corre con ello el riesgo innecesario de desnaturalizar el término jurisdicción aplicado a la competencia del funcionario designado, lo que no sucede, como he intentado explicar, con la utilización de la expresión Jurisdicción Voluntaria referida a Secretarios Judiciales, Notarios y Registradores, por razones históricas, de derecho comparado y de ubicación funcional en el seno del propio órgano jurisdiccional.

Parecería por ello más conveniente que en vez de prever una lista abierta de funcionarios en la Ley Marco reguladora de la JV, se atribuyan competencias específicas, en la propia Ley de JV o en otras disposiciones legislativas, a funcionarios singulares, como los Cónsules o los Registradores de Bienes Muebles, como así se establece en el caso de los Registradores de Bienes Muebles en la Disposición Final segunda, $13^{\circ}$, por la que se modifica el art. 274 de la LH, conforme al cual: $<$....Los Registradores de la Propiedad, Mercantiles y de Bienes Muebles tienen el carácter de funcionarios públicos para todos los efectos legales.............En su condición de funcionarios públicos ejercerán aquéllas funciones en materia de jurisdicción voluntaria que la legislación específica les atribuya.....>.

En relación con los Cónsules, su competencia viene prevista en el Procedimiento denominado "Protesta de Mar e incidencias de viaje “, art. 190.1: $<$ En los casos en que la legislación aplicable exija que el capitán al llegar al puerto de destino haga constar algunas incidencias del viaje, deberá hacerlo ante la Capitanía Marítima, de acuerdo con lo dispuesto en la ley general de navegación marítima .Si se tratara de un país extranjero ante el cónsul español>.

En el sentido expresado, a mi jucio, la competencia de los cónsules en materia de JV podría asimismo haberse previsto:

a) En relación con la regulación de la competencia en materia de Derecho Internacional, correspondiente al Título II, Capítulo II, arts. 9 a 11.

b) En materia de declaración de herederos abintestato, el Anteproyecto de 2005, preveía en en el art. 286.3 que: < Cuando el causante no hubiera tenido en ningún momento su domicilio en España, se podrá realizar la declaración de herederos mediante acta de notoriedad por el cónsul de su domicilio>, se trataba con ello de colmar una laguna legal que afectaba a los españoles que, residentes en el extranjero, no hubieran tenido en ningún momento residencia en España.

c) Se prevé la intervención de los Cónsules en materia de testamentos cerrados u ológrafos, en la nueva redacción que se propone del art. 736 C.C., en la Disposición Final Primera, $9^{\circ}:<$ El agente diplomático o funcionario consular en cuyo poder hubiera depositado su testamento ológrafo o cerrado un español , lo remitirá al Ministerio encargado de asuntos exteriores una vez conocido el fallecimiento del testador, junto con el certificado de defunción, si obra en su poder>. Dado que el Cónsul, en estos casos, cumple una función notarial, podría reconcérsele competencia para proceder a la apertura y adveración del testamento. 
Las novedades que introduce el texto del art. 736 son: la sustitución de "agente consular" por "agente diplomático o consular", "Ministerio de Estado" por "Ministerio encargado de asuntos exteriores" y la obligación del Ministerio de Estado de "publicar en el BOE la noticia del fallecimiento", se sustituye por la obligación del Ministerio de "remitir el testamento al Juzgado".

d) En materia de Derecho marítimo, en el Procedimiento denominado "Depósito y venta de mercancías y equipajes en el transporte marítimo", en aquellos casos en los que el lugar en que concluya el transporte esté en un país extranjero.

En el Anteproyecto de 2005, se preveía asimismo la competencia del cónsul en los procedimientos de Enajenación de efectos mercantiles alterados o averiados, arts 284 y 285 y de Autorización judicial para la venta del buque, arts. 304 a 306, ambos suprimidos en el Proyecto de Ley.

En cuanto a las atribuciones de los Jueces de Paz en materia de JV, el Proyecto de Ley establece que:

a) Serán competentes para conocer de los actos de conciliación que le correspondan por el domicilio del requerido (art. 30)

b) Lo convenido en acto de conciliación se ejecutará por el Juez de Paz ante el que se celebró la conciliación, cuando por la cuantía sea de su competencia (art. 37.2)

c) Deberá prestar la autorización para la extracción y trasplante de órganos de un donante vivo, en aquellos supuestos que desempeñe la función de Juez encargado del Registro Civil de la localidad en que ha de realizarse la extracción.

En relación con la asignación de competencias específicas atribuidas a los distintos operadores jurídicos en el Proyecto de Ley, procederé a realizar alguna observación por si resultase susceptible de ser tomada en consideración:

a) Parecen más propias de la competencia judicial, en garantía de derechos, sin reserva jurisdiccional, que de la competencia de los Secretarios Judiciales o Notarios:

a.2) La valoración de las cuentas del albacea (art. 153); y

a.3) La autorización para que el albacea pueda efectuar actos de disposición sobre bienes de la herencia (art. 155, $4^{\circ}$ ).

Se trata de actuaciones que, por su propia naturaleza, parecen refractarias, conforme a la actual posición de estos operadores jurídicos en el Ordenamiento, con la función notarial o la propia del secretario judicial.

b) Parece razonable que se atribuya a los Secretarios Judiciales la competencia compartida con los Notarios en materia de Declaraciones de herederos abintestato a favor de los ascendientes, descendientes y cónyuge viudo. La exclusividad competencial en esta materia a favor de los Notarios, en el contexto actual de competencias compartidas entre estos dos operadores jurídicos, titulares de la fe pública judicial los Secretarios y de la fe pública extrajudicial los Notarios, no parece estar justificada, por lo que la disposición de la Ley 10/1992, de 30 de abril, de Medidas Urgentes de la Reforma Procesal, que modifica en este sentido 
el art. 979 de la LEC de 1881, para atribuir a los Notarios, en sustitución de los Jueces , la mencionada competencia exclusiva, y que ciertamente resultó un acierto, en atención a casi nula conflictividad producida al respecto desde su entrada en vigor, debería ser revisada en el sentido de reconocer la competencia compartida a Notarios y Secretarios Judiciales en relación con los herederos abintestato de toda condición, como así se había previsto en la regulación del procedimiento específico, arts. 186 a 191, del Anteproyecto de 2005.

En sentido contrario al indicado, de supresión de la exclusividad notarial, el Proyecto modifica la regulación que en materia de testamento cerrado había previsto el Anteproyecto de 2005, conforme al cual cuando el testamento cerrado estaba depositado en el Archivo de un Notario le correspondía a éste en exclusiva la apertura, adveración y protocolización del mismo, y de conformidad con este tenor se modificaba el art. 712 del CC, mientras que en los supuestos en que el testamento había quedado en poder del testador o de una tercera persona, quien tuviese el testamento en su poder podía optar por acudir a un Notario o al Juzgado para proceder a su presentación, adveración y, en su caso, posterior protocolización, y así se preveía en la modificación del art. 714 del CC.

Pues bien, conforme a la regulación prevista en el Proyecto, desaparece la exclusividad competencial del Notario que tenga en su archivo el testamento para proceder a su adveración y apertura y el interesado podrá optar por otro Notario o por el Secretario Judicial competente para la realización de las formalidades requeridas, art. 712. Sin embargo, aunque no se prevé de forma expresa, parece evidente, y será lo más frecuente, que el interesado que opte por el cauce notarial, puede decidir que sea el propio Notario que ha autorizado su otorgamiento, quien proceda a la adveración, apertura y protocolización del testamento.

Ahora bien,en la Memoria Justificativa del Proyecto, apartado IV, parece que por error, se continua distinguiendo entre aquellos supuestos en los que el testamento cerrado está depositado en el Archivo del Notario, en los que se reconoce a éste la competencia exclusiva para su adveración y apertura y aquellos supuestos en que el testamento no se encuentra en el Protocolo notarial, en los que el interesado podrá optar por acudir a la intervención del Notario o a la del Secretario Judicial .

La exclusividad de la competencia de los Secretarios Judiciales se articula, asimismo, en el Proyecto en relación con los siguientes supuestos:

a) Subastas judiciales no ejecutivas, arts. 128 a133.

b) Declaración de extinción de la obligación en la consignación, conforme al art. 127, 3 .

c) Robo, hurto o extravío o destrucción del título al portador, arts. 177 a 180.

d) Orden de venta de bienes o efectos depositados, conforme al art. 186, en el procedimiento de depósitos en materia mercantil.

e) Nombramiento de perito en los contratos de seguros, arts. 187 y 188

f) Protesta de mar e incidencias de viaje, arts.190 y 191 
g) Liquidación judicial de avería gruesa, arts.192 a 197.

La conciliación se atribuye en exclusiva asimismo al Secretario Judicial, salvo en aquellos supuestos que el requerido tenga su domicilio en un municipio donde no exista Juzgado de Primera Instancia o Mercantil, cuando se trate de materias de su competencia, en cuyo caso será competente para conocer del acto de conciliación el Juez de Paz, conforme al art. 30.

No se prevén competencias compartidas con ningún otro operador jurídico, en los supuestos de actos de JV cuyo conocimiento y resolución se atribuye a los Jueces.

Las competencias compartidas se conforman: o entre Secretarios Judiciales y Notarios; o entre Secretarios Judiciales y Registradores de la Propiedad o Registradores Mercantiles; o entre Secretarios Judiciales, Notarios y Registradores de la Propiedad o Mercantiles, en determinados expedientes en los que los ciudadanos pueden optar por solicitar la tramitación del expediente ante cualquiera de los tres operadores jurídicos, como sucede por ej. en el expediente de dominio, art. 115; el expediente de liberación de gravámenes, art. 120; la exhibición de libros de las personas obligadas a llevar la contabilidad, art.159; la constitución y régimen interno del sindicato de obligacionistas de personas jurídicas que no sean sociedades anónimas, art.170; la nota marginal de doble inmatriculación, prevista en el art. $312.2^{\circ}$ del Reglamento Hipotecario, conforme a la Disposición Adicional Segunda a) y la Disposición Adicional tercera b); o el Procedimiento para completar las circunstancias de los títulos para practicar anotaciones preventivas, previsto en el art. 74 de la Ley Hipotecaria, conforme a la D. A. segunda b) y a la D. A. tercera c).

Asimismo en relación con los Secretarios Judiciales, podría preverse una cláusula general, conforme a lo establecido en el art. 5.3 del Anteproyecto de 2005, en la que se estableciese de forma expresa que $:<$ En los casos en que la resolución definitiva del expediente corresponda al Juez, el Secretario Judicial llevará a cabo toda la tramitación excepto la comparecencia y la admisión y práctica de pruebas>, lo que redundaría en la agilización del expediente, y ayudaría a atenuar al la sobrecarga de trabajo de los Jueces. Cabe, en todo caso, señalar que la aplicación supletoria al respecto de la LEC podría, en la práctica, producir el mismo resultado que la aplicación de la aludida cláusula específica.

ii. En relación con la atribución de competencias a los Notarios, cabe señalar, el amplio reconocimiento que al respecto se materializa en el texto del Anteproyecto, en materia de derechos reales, obligaciones, sucesiones, derecho mercantil y derecho marítimo y, a salvo de las reservas formuladas, en materia de plazo para el cumplimiento de la obligación y en aspectos puntuales en sede de albaceazgo cabría, no obstante, a mi juicio, la adición al texto definitivo de los siguientes supuestos - con carácter compartido con los Secretarios Judiciales -, a los que ya me he referido en estudios anteriores: 
a) La presencia y documentación que requiere un matrimonio civil, es una función propia de la labor del Notario y del Secretario Judicial.

b) La separación y divorcio por mutuo consenso, podría asimismo formalizarse ante Notario o Secretario judicial, salvo la aprobación del convenio regulador, en los casos de existencia de menores de edad o incapacitados, que deberá ser aprobado por el Juez.

c) En las uniones de hecho podría regularse la función acreditadora y documentadora del Notario respecto a la existencia real de la convivencia y al tiempo de relación previo a tal acto de constatación.

d) En materia de adopción de mayores de edad y de menores emancipados.

e) La reconciliación que el art. 84 del CC. exige que los cónyuges pongan en conocimiento del Juez, a fin de poner término al procedimiento de separación y dejar sin efecto ulterior lo en él resuelto, podría acreditarse mediante acta notarial.

f) La formalización de inventarios prevista en diversos textos del Código Civil y Ley de Enjuiciamiento Civil y atribuida al Juez, encaja mejor en la función propia de los Notarios y Secretarios Judiciales. Al efecto, en el Anteproyecto de 2005 se había regulado en el artículo 15, ubicado en sede de procedimiento general, la práctica del inventario de bienes.

g) La posesión judicial de bienes a favor de quienes los hubieren adquirido por herencia, si no estuvieren siendo poseídos por nadie a título de dueño o usufructuario - es decir, el tradicional interdicto de adquirir la posesión, conforme a la denominación clásica sustituida, a mi juicio, de forma equivocada, por una larga perífrasis, en el art. 250.3 LEC - podría atribuirse al Notariado y a los Secretarios Judiciales, como expediente de JV.

h) La posesión judicial en los casos en que no proceda el interdicto de adquirir, que conforme a la previsión del Proyecto, pasaría a la competencia de los Secretarios Judiciales, art. 13.3, es asimismo materia cuyo conocimiento y resolución debería atribuirse, de forma compartida, a Notarios y Secretarios Judiciales.

i) Las subastas judiciales no ejecutivas, arts. 128 a 133 del Proyecto, atribuidas en exclusiva a los Secretarios Judiciales, constituyen asimismo actuaciones propias de la función notarial, al igual que ya sucede respecto a la realización extrajudicial ejecutiva de bienes de naturaleza diversa, por lo que convendría establecer su carácter de expediente compartido por ambos operadores jurídicos. Se trataría con ello de En este sentido, se establecía en el Anteproyecto de 2005, art. 171.3 que: <Salvo que la Ley o el tribunal que la hayan ordenado expresamente dispongan lo contrario, los interesados podrán instar la enajenación en subasta notarial, inicialmente o en cualquier momento anterior al anuncio de la subasta. En tal caso, se sobreseerá el expediente judicial de subasta si se hubiere iniciado>.

j) La protocolización de memorias testamentarias, en los derechos civiles especiales en los que exista como institución propia . 
k) La manifestación del heredero, que se hubiese reservado el derecho de deliberar, relativa a la aceptación o el repudio de la herencia, a la que se refiere el art. 1019 CC, deberá realizarse ante el Secretario Judicial, y debería preverse asimismo la competencia notarial.

l) Los testamentos militar y marítimo, arts. 716 a 721 y 722 a 731 CC, o determinadas manifestaciones testamentarias de Derecho Civil de Comunidades Autónomas, en los que no ha intervenido el Notario, requieren la acreditación de su autenticidad y la comprobación del cumplimiento de los requisitos y formalidades legales, lo que constituye una función propia de la actuación notarial. Lo mismo cabría afirmar del testamento realizado en peligro de muerte inminente, en tiempo de epidemia, arts. 700 a 704 CC, o en caso de naufragio, art. 731 CC, en los que la actuación consistente en autenticar, calificar y documentar las afirmaciones de los testigos, constituyen una función propia de la actuación notarial, como sucede, en general, en una materia, como la testamentaria, esencialmente notarial desde el originario derecho romano, en el que tabeliones eran juristas prácticos especializados en testamentos y contratos.

m) El procedimiento de protesta de mar e incidencias de viaje, arts. 190 y 191 del Proyecto, en cuanto que se trata de un acto de documentación y presencia, propio de la función notarial.

iii. En relación con las competencias de los Registradores de la Propiedad y Registradores Mercantiles, cabe resaltar, en una primera aproximación, el amplio reconocimiento de atribuciones previstas en el Proyecto en el ámbito de los derechos reales y del derecho mercantil. Con la finalidad asimismo de contribuir a la posible mejora del marco competencial de estos operadores jurídicos, contenido en cuerpos legales diversos, se formula las consideraciones que siguen.

Constituye una relevante novedad el reconocimiento de competencia a los Registradores de la Propiedad para resolver Expedientes de Dominio, art. 115 y Expedientes de Liberación de gravámenes, art. 120, para lo que se procede a la modificación de los arts. 201 y 210 de la Ley Hipotecaria, contenida en la Disposición final segunda, apartados $9^{\circ}$ y $11^{\circ}$. Convendría, sin embargo, reflexionar, al respecto, sobre la conveniencia de prever las oportunas sustituciones, conforme a lo regulado en el art. 275 bis de la Ley Hipotecaria, a fin de que en los supuestos indicados, como en aquellos otros que tengan una naturaleza análoga, no recaiga en el mismo Registrador la competencia para resolver el expediente y al propio tiempo para proceder a la inscripción del documento que corresponda en el Registro.

La titularidad de los expediente mencionados es compartida con los Secretarios Judiciales, regulándose los correspondientes procedimientos en los capítulos II y III, del Título VI del Proyecto, Jurisdicción Voluntaria en materia de derechos reales, y Notarios, si bien en relación con estos operadores jurídicos no se prevé la actuación notarial al respecto, por lo que habrá que esperar a una futura modificación legislativa, conforme a la Disposición adicional segunda que 
prevé que: <El Gobierno llevará a cabo las modificaciones y desarrollos reglamentarios que sean precisos para la aplicación de la presente ley>.

Cabe destacar asimismo el reconocimiento de competencias a los Registradores Mercantiles en materia de nombramientos, expertos en cuestiones societarias, en la mayoría de los supuestos:

a) Nombramiento y revocación de auditor de cuentas, conforme a la Disposición Adicional cuarta d). En el art. 163 se prevé, por otra parte, que $<$....la solicitud de auditoría de las cuentas de los empresarios pueda efectuarse ante un Registrador Mercantil $>$. Se modifican al respecto los arts. 205 y 206 dela LSA, en la Disposición final sexta.

b) Nombramiento de Presidente de junta o asamblea general, conforme al art. 167: <...cuando se trate de entidades inscritas en el Registro Mercantil, si la junta general o asamblea ordinaria o extraordinaria no pudiera ser convocada por carecer la entidad de administradores o liquidadores en su caso, el Registrador Mercantil correspondiente, a solicitud de cualquiera de los socios o miembros, podrá convocar dicha junta o asamblea general a los solos efectos de que se proceda al nombramiento de tales cargos y nombrará Presidente de entre los socios o miembros, el cual estará facultado para requerir la presencia del Notario>.

c) Designación de un interventor que fiscalice las operaciones de liquidación, a petición de accionistas que representen la vigésima parte del capital social, conforme al art. 175 y a la Disposición adicional cuarta, c). (art 269 LSA).

d) Designación del liquidador en los supuestos de los apartados 2 y 3 del art. 110 de la Ley de Sociedades de Responsabilidad Limitada., conforme a la Disposición adicional cuarta, c.

e) El nombramiento de codaministrador en las compañias mercantiles previsto en el art. 132 del C.Co., conforme a la Disposición final cuarta, a.

f) La designación de experto independiente que fije la cuantía de la indemnización compensatoria, a solicitud del socio que se considere perjudicado por la relación de canje establecida, siempre que así se hubiera previsto en estatutos o decidido expresamente por las Juntas que acuerden la fusión o escisión de sociedades, conforme a la Disposición adicional cuarta, a.

En esta línea de previsión de competencias en materia societaria, podría incluirse en la futura Ley, la competencia de los Registradores Mercantiles para : Emitir dictamen no vinculante sobre el cumplimiento o no, por parte de la sociedad , de los derechos de información que legalmente correspondan al socio. Se trata del reconocimiento de una competencia, ya prevista en el Anteproyecto de 2005, que podría tener un efecto antilitigioso en las relaciones entre los socios y la sociedad. 


\section{$X$ DE LOS PROCEDIMIENTOS ESPECIALES}

Procederé, a continuación, a formular algunas consideraciones acerca de la regulación de los procedimientos específicos, contemplados en el Proyecto, que abarca un total de treinta y siete: la conciliación y once en materia de personas, dos de derecho de familia, tres de derechos reales, tres de derecho de obligaciones, seis en materia de sucesiones, ocho de derecho mercantil y tres de derecho marítimo.

Se ha suprimido en el Proyecto el procedimiento de mediación judicial previsto en el Anteproyecto de 2005. Constituía la mediación una de las más relevantes innovaciones de la propuesta de la Ponencia. Se había querido al recoger esta figura, como se explicaba en la Memoria Justificativa, dar respuesta a las recomendaciones internacionales de realizar esfuerzos en aras a disminuir la conflictividad judicial y la petición de un importante sector doctrinal que pedía su introducción. Se le planteó incluso a la Ponencia la oportunidad de regular la mediación extrajudicial, lo que se desechó al entenderse que se excedía con ello del mandato recibido. En el articulado se establecía que la mediación tendría lugar cuando las partes, en cualquier momento del procedimiento, solicitasen la suspensión del curso del litigio, para intentar alcanzar un acuerdo contando con la actividad mediadora de un tercero.

Se permitía, incluso conforme a la previsión legal, que el Tribunal de oficio, y con suspensión del curso de los autos, remitiese a las partes a mediación cuando, después de las alegaciones iniciales de las partes, no hubiese sido posible lograr un acuerdo en el momento previsto legalmente para ello, siempre que se apreciase, en resolución motivada y oídas las partes, que todavía era posible y conveniente, a través de la actuación de un mediador, conseguir una solución negociada, teniendo particularmente en cuenta la naturaleza de la controversia, el interés público en ella ínsito o las consecuencias personales y sociales de la conflictividad en el supuesto específico.

Se regula la conciliación, arts. 29 a 38, atribuyéndose la competencia al Secretario Judicial o al Juez de Paz, conforme a las previsiones del art. 30. Sin embargo, se suprime la conciliación intraprocesal, que constituía una de las principales novedades de la regulación del Anteproyecto de 2005. Al respecto se pronunciado Seoane Cacharrón, en su examen comparativo entre el Anteproyecto del Ministerio de Justicia y el elaborado por la Ponencia, en el sentido de considerar más conveniente el mantenimiento de la posibilidad de conciliación en todas las instancias del proceso, incluso en la ejecución, en línea con la Recomendación del Consejo de Europa de 16 de septiembre de 1986.

Salvo en el aspecto indicado la regulación de la conciliación en el Proyecto reproduce, en íineas generales, la prevista en el A.2005, y en relación con el Anteproyecto 2006, establece en el art. 32 que los actos de comunicación podrán practicarse por el procurador de la parte solicitante si así lo pidiere, y en el art. 36 
que se dará testimonio de la solicitud de conciliación y de los documentos aportados al interesado o interesados que lo pidieren.

Constituye una novedad la regulación del procedimiento para obtener la autorización o aprobación judicial del reconocimiento de la filiación no matrimonial, arts. 39 a 42. Cabe destacar al respecto la legitimación a favor del padre o la madre autores del reconocimiento, así como del reconocido o de su representante legal, según los casos. Asimismo se configura como una innovación, respecto de lo previsto en los Anteproyectos anterior, la previsión, contenida en el art. 42.2, in fine, de que alcanzada por el reconocido la plena capacidad podrá, mediante declaración auténtica, invalidar, si no lo hubiere consentido, la determinación de la filiación realizada por el Juez durante su minoría de edad o incapacidad.

Se regula en un procedimiento específico, la habilitación para comparecer en juicio y el nombramiento de defensor judicial de menores e incapaces, previsto en el art. 300 del CC.

Se hace referencia, en lo que constituye una novedad en las leyes procesales, a la adopción internacional, estableciéndose al respecto que se estará a lo previsto en el art. 9.5 del CC, así como a lo establecido al respecto en los Convenios internacionales en que España sea parte, conforme al art. 58. Constituye asimismo una novedad, ya prevista en los anteriores Anteproyectos que, en los supuestos de expedientes sobre acogimiento de menores y adopción, la competencia recaiga en el Juzgado de la sede de la entidad pública que tenga encomendada la protección de menores y, sólo en su defecto, en el del domicilio del adoptante, conforme al art.14.2,3 ${ }^{\mathrm{a}}$.

En el Procedimiento por el que se regulan las medidas relativas a la sustitución de menores en los supuestos de sustracción internacional, arts.59 a 67, se incorpora como novedad lo previsto en el Reglamento CEE n 22012003 DEL Consejo, relativo a la competencia, el reconocimiento y la ejecución de resoluciones judiciales en materia matrimonial y de responsabilidad parental.

Constituye una novedad la regulación específica del procedimiento para obtener la autorización judicial para las autorizaciones legítimas en el ámbito del honor, la intimidad personal y familiar, y la propia imagen del menor o incapacitado, cuando el Ministerio Fiscal se hubiere opuesto al consentimiento otorgado por su representante legal, arts. 76 y 77.

En relación con el procedimiento relativo a la autorización judicial para realizar actos de disposición o gravamen sobre bienes o derechos de menores o incapaces y para transigir acerca de sus derechos, arts. 78 a 83, cabe resaltar que se permite que la autorización se extienda a la celebración de venta extrajudicial directa, sin necesidad de subasta ni intervención de persona o entidad especializada

En la regulación de la protección del patrimonio de las personas con discapacidad, arts. 74 y 75, se establece que la apelación será recurrible con efectos suspensivos, salvo en el caso del art. 5.6 de la Ley 412003 . 
Constituye una novedad, al tiempo que un notable acierto, la regulación de los procedimientos correspondientes a: La autorización judicial de los tratamientos no voluntarios de las personas con trastornos psíquicos, arts. 84 a 87, y La extracción de órganos de donantes vivos, arts.99 a 101.

Los procedimientos en materia de derecho de familia se reconducen a:

a) La solución de controversias en el ejercicio de la patria potestad, arts.106 a 108, que abarca supuestos como, la discordancia sobre la conveniencia de operar o no a un hijo, el colegio a elegir para su formación, la realización o no de una trasfusión de sangre, el ejercicio de la custodia del menor cuando los padres vivan separados, las relaciones de los menores con el padre o la madre que no ejerza la patria potestad o con sus parientes o allegados, las relaciones del menor en régimen de acogimiento con los progenitores el régimen de visitas, la adopción de providencias necesarias para la administración y recaudo de los bienes del menor, cuando la administración de los padres ponga en peligro el patrimonio de los bienes de sus hijos etc.

b) La intervención judicial en los casos de descuerdo conyugal y en la administración de bienes gananciales, arts. 109 ss , en la que quedan englobados supuestos como la fijación del domicilio, la disposición de la vivienda, la contribución de un cónyuge a las cargas del matrimonio etc.

En relación con el Expediente de dominio, arts.114 a 118, cabe destacar:

a) la ampliación el marco competencial a Secretarios Judiciales, Notarios y Registradores Mercantiles, al que ya he aludido en un apartado anterior;

b) el traslado de la regulación contenida en la Ley Hipotecaria al texto del Proyecto como un procedimiento específico

c) la supresión de la intervención del Ministerio Fiscal, lo que cabe entender en consonancia con lo que supone una modificación relevante respecto de lo previsto en el actual 1815 LEC 1881, y al A. 2005 que establece la intervención del Ministerio fiscal cuando el procedimiento afecte a intereses públicos, lo que podría plantearse si en el expediente se viesen afectados intereses de ausentes o de personas en paradero desconocido o propiedades públicas, si bien hay que hacer constar que en el Informe del Consejo Fiscal se justifica la supresión de la intervención del Fiscal en estos supuestos, en atención a: $<$ que dichos expedientes atañen meramente a intereses privados y así lo pone de manifiesto el hecho de que no esté prevista la intervención del Fiscal en el ulterior proceso contencioso si se llega a entablar contienda>.

Se ha trasladado asimismo la regulación del Expediente de regulación de cargas y gravámenes - respecto de la que cabe, en líneas generales, extender la exposición formulada respecto del expediente anterior - contenida en la Ley Hipotecaria, al texto normativo del Proyecto, arts.119 a 122.

En relación con la consignación, arts. 125 a 127, se reconoce la competencia del Secretario Judicial y del Notario, si bien hubiera sido deseable haber mantenido 
la propesta de modificación del art. 1178 CC, formulada por el A. 2005, en orden a la previsión de actuación notarial. En todo caso, es competencia del Notario declarar, en su caso, bien hecha la consignación, es decir, cumplidos los requisitos de identidad e integridad de la prestación, si bien sólo el Secretario podrá declarar cancelada la obligación, conforme al art. 127.3 del Proyecto

A los procedimientos en materia de sucesiones ya me he referido en otro apartado de este estudio. Sí conviene resaltar que el procedimiento de protocolización del testamento ológrafo ha sido trasladado del CC al Proyecto de Ley de JV, arts. 144 a 148, y que se ha suprimido, sin que ello esté justificado, a mi juicio, en la tramitación del expediente, la referencia a la oposición, del párrafo segundo del actual art. 693 CC, conforme al cual: <Cualquiera que sea la resolución del Juez, se llevará a efecto, no obstante oposición, quedando a salvo el derecho de los interesados para ejercitarlo en el juicio que corresponda>.

La temática sucesoria en el A. de 2005 y en el Proyecto de Ley, ha sido, respectivamente, estudiada con detalle, por Juan José Marín, en una comunicación presentada a las XII Jornadas de la Asociación de Profesores de Derecho Civil, en Cantabria, febrero de 2006 y José María De Prada, en Ponencia presentada en el Colegio Notarial de Madrid en octubre de 2006, ambas en prensa, y que he podido consultar por cortesía de los autores.

En relación con los procedimientos de derecho mercantil y de derecho marítimo, me remito, asimismo, a lo ya expuesto, al respecto, en diversos apartados del presente estudio.

Cabría finalmente señalar que resulta justificada la determinación del carácter preferente de determinados procedimientos, como el retorno de menores en supuestos de sustracción internacional, art. 66, el acogimiento o la adopción,art. 49.3, así como la ausencia de efectos suspensivos del recurso de apelación, salvo que la Ley disponga expresamente lo contrario, lo que sucede por ejemplo en supuestos de adopción o venta de bienes de menores e incapacitados si bien en algún supuesto, como el de retorno de menores parece más apropiado un cambio de criterio, al efecto de prever el efecto suspensivoi (Endnotes).

En relación con la bibliografía sobre jurisdicción voluntaria, además de la ya indicada en la primera parte de este estudio, cabe hacer referencia, entre otras, a las siguientes publicaciones :

\section{ఔ DE LAS DISPOSICIONES COMPLEMENTARIAS}

En la Disposición Adicional $1^{\text {a }}$ establece que las referencias a asuntos (sería más correcto : actos) de JV en normas de fecha anterior a esta Ley, a la LEC, se entenderán hechas a la presente Ley .Asimismo que las referencias a las competencias del Juez, que efectúen leyes de fecha anterior a la presente, se entenderán hechas al Juez o al Secretario Judicial. 
En las Disposiciones Adicionales $2^{\circ}, 3^{\circ}$ y $4^{\circ}$, se mencionan diversos expedientes previstos en diversos cuerpos legales del Ordenamiento - singularmente la Ley Hipotecaria, el Reglamento Hipotecario, el Código de Comercio, la Ley de Sociedades Anónimas, la Ley de Responsabilidad Limitada y el Reglamento del Registro Mercantil -, que no se ha considerado oportuno trasladar como procedimientos específicos al texto normativo del Proyecto, y cuya titularidad se atribuye de forma compartida a : Secretarios Judiciales y Notarios; Secretarios Judiciales y Registradores de la Propiedad y Secretarios Judiciales y Registradores Mercantiles.

En la Disposición Adicional 5a , se establece el compromiso del Gobierno de aprobar los aranceles de derechos correspondientes a la intervención de los Notarios y Registradores de la Propiedad y Merantiles.

En la Disposición Adicional $6^{\circ}$, se contiene el compromiso del Gobierno relativo a las modificaciones y desarrollos reglamentarios precisos para la aplicación de la presente Ley .

En la Disposición Adicional 7a , se reconoce competencia al Juez de Violencia sobre la Mujer en materia de jurisdicción voluntaria.

En la Disposición Transitoria única se regula el régimen de los expedientes en tramitación.

En la Disposición Derogatoria única se establece la derogación de los artículos correspondientes a la materia de la LEC 1881, al propio tiempo que la vigencia de las previsiones de esta Ley de 1881, hasta la fecha de entrada en vigor de la Ley General de Navegación Marítima. En el momento actual ambas leyes, la de Jurisdicción Voluntaria y la de Navegación Marítima, están en fase de tramitación parlamentaria.

El apartado segundo de esta Disposición derogatoria, podría no contemplarse sin menoscabo del texto legal, al referirse a que quedan derogadas, conforme al apartado segundo del artículo 2 del Código Civil, cuantas normas se opongan o sean incompatibles con lo dispuesto en la presente Ley.

En la Disposición Finales $1^{\mathrm{a}}$ a $6^{\mathrm{o}}$ se modifican determinados artículos: en la $1^{\mathrm{a}}$ del Código Civil, en la $2^{\text {a }}$ de la Ley Hipotecaria, en la $3^{\text {a }}$ de la Ley del Notariado, en la $4^{\mathrm{a}}$ del Código de Comercio, en la $5^{\mathrm{a}}$ de la Ley del Contrato de Seguro y en la $6^{\mathrm{a}}$ de la Ley de Sociedades Anónimas.

Especial detenimiento y comentario merece el nuevo marco normativo de atribución de competencias en materia de jurisdicción voluntaria, contenido en las propuestas de modificación de artículos correspondientes a

- La Ley del Notariado, art.1, en relación con los Notarios:<.....Igualmente como funcionario público, ejercerá aquellas funciones en materia de jurisdicción voluntaria que según la legislación específica se le atribuyan>

- La Ley Hipotecaria, art.16.3, en relación con los 
Registradores de la Propiedad. < En su condición de funcionarios públicos ejercerán aquellas funciones de jurisdicción voluntaria que la legislación específica les atribuya>.

- El Código de Comercio, art 16.3, en relación con los Registradores Mercantiles: <Como funcionario público, el Registrador Mercantil administrará los expedientes de jurisdicción voluntaria que le atribuya el ordenamiento>

Objeto de especial análisis, a mi juicio merece, por su parte, la Disposición Adicional tercera, por la que se modifica el art. 1 de la Ley de Organización del Notariado, y ello en atención a que supone un cambio relevante respecto al actual contenido del art. 1.

En el párrafo segundo del citado artículo se establece: <Como funcionario público - se refiere al Notario - ejerce la fe pública notarial que implica la obligación de dar fe de la identidad de los otorgantes, de que el consentimiento ha sido libremente prestado y de que el otorgamiento se adecua a la legalidad y a la voluntad debidamente informada de aquéllos. Igualmente como funcionario público, ejercerá aquellas funciones en materia de jurisdicción voluntaria que según la legislación específica se le atribuyan>.

A mi jucio, sería conveniente reconsiderar la redacción de este párrafo, en el sentido de:

1) Ajustar mejor la extensión que se atribuye a la fe pública en la reforma

2) Introducir la referencia a los contratos y demás actos extrajudiciales, contenida en el vigente art. 1 de la Ley del Notariado.

El objeto de la dación de fe se refiere a hechos, perceptibles, percibidos y recogidos como tales por el Notario en el documento que otorga. En tal consideración cabe enmarcar la identidad de los otorgantes y la declaración de que el consentimiento ha sido libremente prestado, a lo que cabría añadir que - a juicio del Notario - el otorgamiento se adecua a la legalidad y a la voluntad debidamente informada de los otorgantes, dado que en estos casos parece más bien que estamos, más que ante un ejercicio de la dación de fe en sentido técnico, ante un juicio o una calificación notarial, que podrá ser acertada o errónea.

En definitiva, la propuesta que formulo de revisión del citado párrafo se concretaría en la siguiente redacción del mismo:

$<$ Como funcionario público el Notario ejerce la fe publica notarial , conforme a las leyes de los contratos y demás actos extrajudiciales, lo que implica la obligación de dar fe de la identidad de los otorgantes, de que el consentimiento ha sido libremente prestado y de que, a su juicio, el otorgamiento se adecua a la legalidad y a la voluntad debidamente informada de aquéllos. Igualmente como funcionario público, ejercerá aquellas funciones en materia de jurisdicción voluntaria que según la legislación específica se le atribuyan>. 
En la Disposición Final $7^{\mathrm{a}}$ se prevé el Titulo Competencial y en la $8^{\mathrm{a}}$ la Entrada en vigor, prevista para un año de su publicación en el BOE, salvo las disposiciones contenidas en la presente Ley que atribuyen competencia a los Notarios y Registradores de la Propiedad y Mercantiles, que <sólo adquirirán vigencia si el Gobierno aprueba los aranceles de derechos a que se refiere la disposición adicional quinta de esta Ley>, si bien parece hubiera sido más apropiado la fórmula <que sòlo adquirirán vigencia cuando el Gobierno apruebe los aranceles....>.

Se establece, finalmente, en el apartado 3 que:

$<$ El Título X de la presente Ley- referido al Derecho Marítimo entrará en vigor en la misma fecha en que lo haga la ley general de navegación marítima, si ésta se produjera después de trascurrido el plazo referido en el párrafo primero de esta disposición>

\section{CAT VALORACIÓN FINAL GLOBAL DEL NUEVO MARCO NORMATIVO DE LA JURISDICCIÓN VOLUNTARIA}

Cabría afirmar, en conclusión, que la nueva configuración de la Jurisdicción Voluntaria, racionaliza el sistema, amplia el marco competencial a diversos Cuerpos de Funcionarios, redistribuye competencias en el seno del órgano judicial y articula un procedimiento unitario y respetuoso, en lineas generales, con las exigencias de la tutela judicial efectiva, con reglas precisas de funcionamiento, criterios legales y principios informadores, por lo que merece, a mi juicio, con las salvedades manifestadas en materia de reserva jurisdiccional, garantías y contradicción, una valoración global positiva y debería suponer, en el futuro, la no identificación de la Jurisdicción Voluntaria con supresión o disminución de garantías, plazos o formalidades, al tiempo que podría constituir el punto de partida para la elaboración de una Teoría General de la Jurisdicción Voluntaria que, de forma definitiva, incardine este materia en el campo de la ciencia procesal .y la aleje de la mera técnica procedimental.

\footnotetext{
${ }^{26}$ En relación con la bibliografía sobre jurisdicción voluntaria, además de la ya indicada en la primera parte de este estudio, cabe hacer referencia, entre otras, a las siguientes publicaciones:
}

Vid de forma especial en la doctrina española :

RAMOS MENDEZ, La Jurisdicción Voluntaria en negocios de comercio. Madrid 1978; Id. Derecho procesal civil. T.II, Barcelona 1992, pp 1289ss ; ALMAGRO, con Cortés Domínguez, Gimeno Sendra y Moreno Catena, en Derecho Procesal Civil, tomo I, Vol II, pp.535-593; y GONZALEZ POVEDA, Jurisdicción Voluntaria, $3^{\text {a }}$ Ed.,Pamplona 1997.;AA.V.V. JURISDICCIÓN VOLUNTARIA, Coordinador GONZALEZ POVEDA, Consejo General del Poder Judicial, Madrid 1997

Vid. asimismo sobre Jurisdicción voluntaria en Derecho Romano y en Derecho Procesal vigente:

FERNÁNDEZ DE BUJAN, A., Jurisdicción voluntaria en Derecho Romano, Madrid, $3^{\text {a }}$ ed. 1999,prólogo 
de M.Amelotti; Id., A propósito de la competencia en materia de iurisdictio voluntaria en Derecho Romano, Revista de Derecho Notarial y A.A.M.N., T. XXVIII pp. 95-134; Id., Diferencias entre los actos de iurisdictio contenciosa y iurisdictio voluntaria en Derecho Romano, Estudios Homenaje a A. D’Ors, vol. I, Pamplona, 1987, pp. 427-457; Id., Consideraciones acerca del carácter clásico y jurisdiccional de la denominada por Marciano "Iurisdictio voluntaria”, en D. 1.16.2. pr., Estudios Homenaje a Juan Iglesias, Madrid, 1987, pp. 197-215; Id., “La Jurisdicción Voluntaria”, Ed. Civitas, Madrid, 2001; Id., Jurisdicción voluntaria 2001. La jurisdicción voluntaria en la encrucijada: su conexión con el nuevo modelo procesal de la LEC del año 2000, Derecho y Opinión, Córdoba, 2000, pp.329-342; Id., La jurisdicción voluntaria: racionalización y redistribución de competencias, Libro Homenaje a Sánchez Mera, Madrid 2002, pp. 1997-2036; Id., La Jurisdicción Voluntaria: una reforma legislativa pendiente. Estudios Jurídicos. Ministerio de Justicia, vol. IV, 2002, pp. 537-606; Id., Noción de iurisdictio y etapas. Jurisdicción contenciosa y jurisdicción voluntaria. Portal electrónico de Derecho, IUSTEL, 2002; Id., Los principios informadores de la jurisdicción voluntaria: una propuesta de futuro, Anuario de Derecho de la U.A.M., vol. 3, 2001, pp. 89-149; Id., Consideraciones de lege ferenda en materia de jurisdicción voluntaria y Anteproyecto de Jurisdicción Voluntaria, Revista del Colegio de abogados de Lugo, 2001, pp. 22-24; Id., A propósito del futuro Anteproyecto de Ley de Jurisdicción Voluntaria, Revista del Colegio de abogados de Lugo, 2001, 2002, pp. 18-22. Id., Jurisdicción Voluntaria: naturaleza jurídica y diferencias de procedimiento con la jurisdicción contenciosa, Actualidad Civil, nº 36, 2001, pp. 1277-1306; Id., Jurisdicción voluntaria: sanción constitucional, nº 37, Actualidad Civil 2001, pp. 1317-1341; Id., La reforma legislativa de la jurisdicción voluntaria: reflexiones de presente y perspectivas de futuro, Derecho de los Negocios, ${ }^{\circ}$ 163, 2004, pp. 5-15; Id., Jurisdicción Voluntaria: Historia (I), Tribuna Pública, Mercados, Voz de Galicia, 12-09-2004; Id., Problemas (II), Tribuna Pública, Mercados, Voz de Galicia, 17-09-2004; Id., Interrogantes (III) Tribuna Pública, Mercados, Voz de Galicia, 26-092004; Id., Soluciones (IV), Tribuna Pública, Mercados, Voz de Galicia, 3-10-2004; Id., Jurisdicción voluntaria: reflexiones de presente y futuro. Estudios Homenaje Manuel Albaladejo, tomo I, 2004, pp. 1655-1691; Id., La hora de la Jurisdicción Voluntaria. Estudios Homenaje a Rodríguez Mourullo, 2005, pp.1901-1921; Id., La reforma de la Jurisdicción voluntaria: problemas, interrogantes, soluciones, La Ley 23 de marzo de 2005, pp.1-9; Id., Jurisdicción Voluntaria, ABC. 21-5-2005; Id., La reforma de la jurisdicción voluntaria, Otrosí, Revista del Colegio de Abogados de Madrid, septiembre de 2005, pp.1619; Id., Los profesionales del derecho y la jurisdicción voluntaria. Ponencia General presentada en el XVII Congreso Nacional de Profesores de Derecho Romano de la República Argentina, General Roca, La Patagonia, Octubre de 2005; Id., La protección patrimonial de los discapacitados y la jurisdicción voluntaria a la luz de lo previsto en la Ley 41/2003, de 18 de noviembre, Ponencia presentada en el II Congreso Regional sobre Protección Jurídica del Discapacitado, Burgos, noviembre de 2005, en prensa; Id., "Reflexiones sobre el Anteproyecto de Ley de Jurisdicción Voluntaria”, Estudios Homenaje al Prof. J. González Campos en prensa;Id. El nuevo perfil de la jurisdicción voluntaria en el anteproyecto de ley de octubre de 2005, La Ley, 8 de junio 2005; Id.La jurisdicción voluntaria ,El Anteproyecto de junio de 2006. El Notario del siglo XXI, agosto 2006.; El procedimiento de jurisdicción voluntaria común a jueces y secretarios , en Economist \& Jurist, en prensa;

Competencias notariales en el Proyecto de Ley de Jurisdicción Voluntaria, en El Notario del siglo XXI Vid.,asimismo en la doctrina española: ALVAREZ-CASTELLANOS, El proceso de jurisdicción voluntaria, Revista DE DERECHO Procesal, 1945, pp.331-353. Gimeno Gamarra, Ensayo de una teoría general sobre jurisdicción voluntaria, ACD, 1953, pp. 5 ss.; Carreras, Eficacia de las resoluciones de jurisdicción voluntaria, en Estudios de Derecho Procesal, 1962; Prieto Castro, Reflexiones doctrinales y legales sobre la jurisdicción voluntaria, en Trabajos y orientaciones de Derecho Procesal, Madrid 1964, pp. 585 ss.; Font Boix, El Notariado y la jurisdicción voluntaria, Academia Matritense del Notariado, T. XV, 1967, pp. 272-295; Serra, Naturaleza jurídica de la jurisdicción voluntaria, en Estudios de Derecho Procesal, Barcelona 1969, pp. 619 ss.; Alcalá-Zamora, Estudios de Teoría General e Historia del Proceso, México 1974, tomo 1, pp. 115 ss; GOMEZ ORBANEJA, Y HERCE QUEMADA, Derecho Procesal Civil, $8^{\mathrm{a}}$ ed. Madrid 1976.Ramos Méndez, La jurisdicción voluntaria en negocios de comercio, Madrid 1978; Almagro, El Secretario Judicial y la futura Jurisdicción Voluntaria. III, J.F.P.J., Madrid 1987, pp. 65-72; Muñoz Rojas, Sobre la jurisdicción voluntaria, Actualidad Civil, nº 9, 1989; Id., Actualidad Civil, nº 39, 1990; PEDRAZ, Constitución, Jurisdicción, Proceso, 1990. Fairén, Jurisdicción voluntaria, Juicios sumarios: las confusiones de la historia y su evolución, BICAM, 2/ 1990, pp.19-34; Id. Sobre el paso de la jurisdicción 
voluntaria a la contenciosa. El artículo 1817 de la LEC y la problemática actual, ADC, 1991, pp. 947-969; DIEZ-PICAZO, L.M., Régimen constitucional del poder judicial, Madrid 1991; GOMEZ DE LIAÑO, Derecho Procesal Civil, 2ed.,Oviedo 1992, pp 566 ss.;Martín Ostos, Hacia un nuevo Secretario Judicial español. La Ley no 2946, 25-2-1992; Almagro, con Cortés Domínguez, Gimeno Serra y Moreno Catena, en Derecho Procesal II, vol. I, Parte General. Proceso Civil. Valencia 1992, pp. 535-593; Auger, Reforma de la jurisdicción voluntaria, Anales Academia Matritense del Notariado, 1992, pp. 7-27; Ramos Méndez, Derecho Procesal Civil, t. III, Barcelona 1992, pp. 1289 ss.; Belloch, Notas en torno al Notariado y la jurisdicción voluntaria, Revista Jurídica del Notariado 1992, pp. 9-42.; Gómez Ferrer, Ejercicio de la jurisdicción voluntaria por el notariado, R.J.N., 1993, pp. 9-178; Ortiz Navarrete, Procesos y expedientes de jurisdicción voluntaria sobre menores en la ley orgánica 1/1996, de 15 de enero, de Protección Jurídica del Menor, Actualidad Laboral 1996; DE PRADA, Intervención judicial en el ejercicio de la patria potestad a través del procedimiento de la D.T. $10^{a}$ de la Ley 19/ 1981, Derecho Judicial, 1996, pp.57 ss ;González Poveda, Jurisdicción voluntaria, $3^{\text {a }}$ ed., Pamplona 1997; JUAN SÁNCHEZ, en ORTELLS RAMOS, Derecho Procesal Civil, Aranzadi 2001, pp. 85-97, SÁNCHEZ BARRILAO, Las funciones jurisdiccionales de jueces en garantía de derechos, Madrid 2002; DE LA OLIVA, con I. DIEZ-PICAZO, Derecho Procesal Civil. El proceso de declaración, Madrid 2001, pp. 229 ss.; DE LA OLIVA ,I. DIEZ-PICAZO y VEGAS TORRES, Derecho Procesal. Introducción. Madrid 2002; Seoane Cacharrón, El Secretario Judicial ante la futura ley sobre la jurisdicción voluntaria, Revista del Centro de Estudios Jurídicos del Ministerio de Justicia, 2003, n 3, pp. 91-108; MONTERO AROCA, con GOMEZ COLOMER, MONTON Y BARONA, Derecho Jurisdiccional V I, Parte General y V.II . Proceso civil, Valencia 2005,GOMEZ COLOMER, pp 859ss; LIÉBANA ORTIZ, Notas para el estudio de la naturaleza jurídica de la jurisdicción voluntaria, Redur,3,2005,pp.163-182..

Vid en la doctrina extranjera: Habscheid ,Freiwillige Gerichtsbarkeit, $7^{\mathrm{a}}$ ed.,"'München 1983;Denti, La giurisdizione voluntaria revisitata,Rivista Trimestrale di Diritto e Procedura Civile 1987 y en Studi in onore di E.Allorio, Milano 1989;Allorio, Saggio polemico sulla giurisdizione voluntaria,Revista T.de Diritto e Procedura Civile,1948;Fazzalari,La giurisdizione voluntaria, Padova 1953; Micheli,voce Camera di Consiglio, en En. Dir., Milano 1958,volV; Januzzi, Manuale della volontaria giurisdizione,Milano 2000; Santarcangelo,La Volontaria Giurisdizione I y II, 2003 y la bibliografía allí citada, y con carácter general ,las contribuciones contenidas en Atti del XVII Convengo Nazionale del Processo Civile, Palermo 1989 2Vid. sobre jurisdicción voluntaria notarial en : Font Boix, El notariado y la jurisdicción voluntaria, en Academia Matritense del Notariado, t. XV, 1967, pp.; Almagro, Derecho Procesal, cit., pp. 530 ss.; Solis Villa, La defensa de los consumidores y la función notarial, Estudios Academia Sevillana del Notariado, Madrid 1998; Rodríguez Adrados, Borrador para un Proyecto de Ley de jurisdicción voluntaria notarial y de modificación de determinados artículos del Código Civil, de la LEC y de la L.H, Agosto 1991, Inédito, reseñado y consultado en el estudio de Gómez-Ferrer; Gómez-Ferrer, Ejercicio de la Jurisdicción Voluntaria por el Notario, Revista Jurídica del Notariado, 1993, pp.9-178; Gómez Colomer, con Montero, Montón y Barona, cit., p.903; Auger, Reforma de la Jurisdicción Voluntaria, Anales de la Academia Matritense y del Notariado, 33, 1992, pp. 7-27; Belloch, J.A, Notas en torno al Notariado y la Jurisdicción voluntaria, Revista Jurídica del Notariado, 1993, pp. 9-42; Fernández De Bujan, A., Jurisdicción Voluntaria,cit., pp. 141-162. Rodríguez Adrados, Naturaleza jurídica del documento auténtico notarial, RDN, XLI-XLII, jul-dcb. 1963, pp 71-183; Id., Formación del instrumento público, validez, eficacia y libre circulación del negocio jurídico así documentado, incluso en las relaciones de Derecho Internacional Privado, RDN, XCVII-XCVIII, jul-dcb 1977, pp. 109-38; Id., La persistencia histórica de la oralidad en la escritura pública, Madrid, 1996, pp. 177 ss. Nuñez Lagos, Hechos y derechos en el documento público, Madrid 1950, pp. 414 ss.; De La Cámara, Valor jurídico y aplicaciones de las actas notariales de notoriedad en Derecho español, Madrid, 1950; Rodríguez Adrados, Cuestiones de técnica notarial en materia de actas, RDN, CXXXVI, abril-junio, 1987. MARIN LOPEZ, Derecho de sucesiones y jurisdicción voluntaria, Comunicación presentada en las XII Jornadas de la Asociación de Profesores de Derecho Civil en febrero de 2206, en prensa; DE PRADA GONZALEZ, En torno a la futura Ley de Jurisdicción Voluntaria, El Notario del siglo XXI,n.4 M ADRID 2006, pp 21 a 24:CAMPO GUERRI, Notariado y Jurisdicción Voluntaria, El Notario del siglo XXI, n.6,Madrid 2006,pp.144-147; Rodríguez Adrados, EL principio de veracidad, El Notario del siglo XXI, n.9,seploct .2006 ,pp. 26 ss

Vid sobre jurisdicción voluntaria registral:3Marina, Calificación registral. Reflexiones sobre las vías de impugnación, AAMN, t. 32, 1991, pp. 496 ss.; González Pérez, La impugnación de los actos registrales, 
RCDI, 1955, pp. 413 ss.; Gerona Peña, La jurisdicción voluntaria en el ámbito notarial y registral. Estudios de Derecho Procesal, vol. III, 1996, pp 3936 ss.; Amorós, La buena fe en la interpretación de los problemas hipotecarios, RCDI, 196. A.A.V.V. Jurisdicción Voluntaria y Registro Civil, en Estudios de Derecho Procesal, dirigidos por I DIEZ-PICAZO Y J. MARTINEZ- SIMANCAS, Vol. III, Madrid 1996, pp3775-4016

Vid sobre Secretariado Judicial y jurisdicción voluntaria: 4 Vid. en este sentido en Almagro, El Secretario Judicial y la futura jurisdicción voluntaria. Fe pública Judicial, III Jornadas, Madrid 1987, pp. 65 ss; Pedraz, La nueva secretaría judicial, RPJ, 1992, pp. 85 ss. y Martín Ostos, El Secretario Judicial a examen, Madrid 1994. Sobre atribución de competencias específicas a los Secretarios Judiciales, vid. Vázquez Sotelo, La intervención de Secretario en el proceso, I.J.F.P.J., Barcelona 1985; Moreno Catena, La Fe Pública Judicial y la publicidad en la LOPJ, II JFPJ, Alicante 1986; Lorca Navarrete, El Secretario Judicial en el contexto de la técnica monitoria civil, VJJFPJ, Salamanca 1990; Habscheid, El Rechtspfleger en Europa, trad. Bujosa, Berlín 1989; Núñez Rodríguez, La intervención del Secretario Judicial en el Registro Civil, IV JFPJ, 1991, Seoane Cacharrón, Hacia un modelo europeo de Secretario Judicial, V JFPJ, Salamanca 1990; Id. El Secretario Judicial ante la futura ley sobre jurisdicción voluntaria, Revista Centro Estudios Ministerio de Justicia 2003, pp. 91-108.Ortiz Navacerrada, El Secretario Judicial en el borrador de Proyecto de la nueva Ley de Enjuiciamiento civil, en Actualidad Civil núm. 33, pp. 15-21 septiembre de 1997. Opinaba ya entonces este autor que mejorarían los rendimientos prácticos del órgano jurisdiccional, si el Secretario Judicial asumiera sin reservas, la totalidad de actuaciones estrictamente ejecutivas que todavía continúan, en parte al menos, residenciadas en el Juez.

\section{CONSIDERAÇÕES SOBRE O PROJETO DE LEI DE JURISDIÇÃO VOLUNTÁRIA NA ESPANHA, DE OUTUBRO DE 2006.}

Resumo: O projeto sob comento trata da distribuição de competência entre juízes e notários, estes como agentes da JV, além de outros aspectos. A reforma legislativa e administrativa enfoca a 'desjudicialização' de procedimentos, em matéria de direitos reais, obrigações, sucessões, direito mercantil e direito marítimo. Aborda diferenças em relação ao anteprojeto de junho de 2006 e os elementos essenciais da reforma, com vistas à racionalização e ampliação do chamado marco competencial para órgãos que estão fora do âmbito do Judiciário. Entende-se que deva haver uma valoração global positiva desta iniciativa - sem supressão ou diminuição de garantias, prazos ou formalidades -, para que se possa desenvolver, no campo da ciência processual, uma Teoria Geral da Jurisdição Voluntária, e não uma mera técnica procedimental.

Palavras-chave: Processo. Jurisdição Voluntária. Direito espanhol. Projeto de lei. 